\title{
Expression of Rem2, an RGK Family Small GTPase, Reduces N-Type Calcium Current without Affecting Channel Surface Density
}

\author{
Huanmian Chen, ${ }^{1}$ Henry L. Puhl III, ${ }^{1}$ Shui-Lin Niu, ${ }^{2}$ Drake C. Mitchell, ${ }^{2}$ and Stephen R. Ikeda ${ }^{1}$ \\ Laboratories of ${ }^{1}$ Molecular Physiology and ${ }^{2}$ Membrane Biochemistry and Biophysics, National Institute on Alcohol Abuse and Alcoholism, National \\ Institutes of Health, Bethesda, Maryland 20892
}

\begin{abstract}
Rad, Gem/Kir, Rem, and Rem2 are members of the Ras-related RGK (Rad, Gem, and Kir) family of small GTP-binding proteins. Heterologous expression of RGK proteins interferes with de novo calcium channel assembly/trafficking and dramatically decreases the amplitude of currents arising from preexisting high-voltage-activated calcium channels. These effects probably result from the direct interaction of RGK proteins with calcium channel $\beta$ subunits. Among the RGK family, Rem 2 is the only member abundantly expressed in neuronal tissues. Here, we examined the ability of Rem 2 to modulate endogenous voltage-activated calcium channels in rat sympathetic and dorsal root ganglion neurons. Heterologous expression of Rem2 nearly abolished calcium currents arising from preexisting highvoltage-activated calcium channels without affecting low-voltage-activated calcium channels. Rem2 inhibition of N-type calcium channels required both the Ras homology (core) domain and the polybasic $\mathrm{C}$ terminus. Mutation of a putative GTP/ $\mathrm{Mg}^{2+}$ binding motif in Rem 2 did not affect suppression of calcium currents. Loading neurons with GDP- $\beta$-S via the patch pipette did not reverse Rem2-mediated calcium channel inhibition. Finally, $\left[{ }^{125} \mathrm{I}\right] \mathrm{Tyr}^{22}$ - $\omega$-conotoxin GVIA cell surface binding in tsA201 cells stably expressing $\mathrm{N}$-type calcium channels was not altered by Rem 2 expression at a time when calcium current was totally abolished. Together, our results support a model in which Rem 2 localizes to the plasma membrane via a $C$-terminal polybasic motif and interacts with calcium channel $\beta$ subunits in the preassembled $\mathrm{N}$-type channel, thereby forming a nonconducting species.
\end{abstract}

Key words: channel; sympathetic; dorsal root ganglion; Rem2; small GTPase; conotoxin

\section{Introduction}

High-voltage-activated (HVA) $\mathrm{Ca}^{2+}$ channels are heterooligomeric complexes consisting of a pore-forming $\alpha$ subunit and auxiliary $\beta$ and $\alpha_{2} \delta$ subunits. At present, seven $\mathrm{Ca}_{\mathrm{v}} \alpha$, four $\beta$, and four $\alpha_{2} \delta$ genes have been cloned. The $\mathrm{Ca}_{\mathrm{V}} \alpha_{1} 1$.x family encodes L-type $\mathrm{Ca}^{2+}$ channels, whereas $\mathrm{Ca}_{\mathrm{V}} \alpha_{1} 2.1, \mathrm{Ca}_{\mathrm{V}} \alpha_{1} 2.2$, and $\mathrm{Ca}_{\mathrm{V}} \alpha_{1} 2.3$ encode $\mathrm{P} / \mathrm{Q}-, \mathrm{N}-$, and R-type $\mathrm{Ca}^{2+}$ channels, respectively. The $\mathrm{Ca}_{\mathrm{v}} \alpha$ subunit contains four homologous domains, with each domain consisting of six transmembrane segments. $\mathrm{Ca}_{\mathrm{v}} \alpha$ subunits determine the ion selectivity and single-channel conductance and contain gating charges within the S4 segments and high-affinity binding sites for peptide neurotoxins. Coexpression of $\mathrm{Ca}_{\mathrm{v}} \beta$ and/or $\alpha_{2} \delta$ facilitates the cell surface trafficking of $\mathrm{Ca}_{\mathrm{v}} \alpha_{1}$, increases $\mathrm{Ca}^{2+}$ current $\left(I_{\mathrm{Ca}}\right)$ amplitude, and alters the channel gating properties (Dolphin, 2003).

\footnotetext{
Received July 27, 2005; revised Sept. 14, 2005; accepted Sept. 19, 2005.

This research was supported by the Intramural Research Program of the National Institutes of Health/National Institute on Alcohol Abuse and Alcoholism. We are very grateful to Dr. Diane Lipscombe (Brown University, Providence, RI) for the gift of tsA201 cells stably transfected with $\mathrm{Ca}_{\mathrm{v}} \alpha_{1} 2.2 / \beta 3 / \alpha_{2} \delta$. We thank Dr. T.-C. He (Johns Hopkins University, Baltimore, MD) for providing the AdEasy system.

Correspondence should be addressed to Dr. Stephen R. Ikeda, Laboratory of Molecular Physiology, National Institutes of Health/National Institute on Alcohol Abuse and Alcoholism, Fishers Lane 5625, Room TS11, MSC 9411 Bethesda, MD 20892-9411.E-mail: sikeda@mail.nih.gov.

D01:10.1523/JNEUROSCI.3111-05.2005

Copyright $\odot 2005$ Society for Neuroscience $\quad$ 0270-6474/05/259762-11\$15.00/0
}

Using $\mathrm{Ca}_{\mathrm{v}} \beta_{3}$ as bait, a yeast two-hybrid screen identified Kir/ Gem (Béguin et al., 2001) as an interacting protein. Overexpression of Kir/Gem prevents de novo L-type $I_{\mathrm{Ca}}$ expression and decreases endogenous HVA- $I_{\mathrm{Ca}}$ density (Béguin et al., 2001; Murata et al., 2004; Ward et al., 2004). Kir/Gem, originally cloned from lymphocytes (Cohen et al., 1994; Maguire et al., 1994), is a member of the recently defined RGK (Rad, Gem, and Kir) family of Ras-related small GTP-binding proteins. The distinct structural features of the RGK family include the following: (1) substitution of critical amino acid residues within the central Rashomologous domain involved in GTP/GDP binding and GTP hydrolysis; (2) a unique $\mathrm{G}_{2}$ domain putatively involved with effector interactions; (3) long $\mathrm{N}$ and $\mathrm{C}$ termini relative to other Ras-like molecules; and (4) a polybasic $\mathrm{C}$ terminus lacking the typical prenylation site present in virtually all other Ras-like GTPases (Reynet and Kahn, 1993; Finlin and Andres, 1997; Finlin et al., 2000). Like Kir/Gem, the other RGK family members, including Rad, Rem, and Rem2, also interact with $\mathrm{Ca}_{\mathrm{v}} \beta$ subunits and prevent de novo expression of L-type $I_{\mathrm{Ca}}$ (Finlin et al., 2003, 2005). Accordingly, it might be presumed that members of the RGK family use a unified mechanism to inhibit L-type $\mathrm{Ca}^{2+}$ channels. However, examination of L-type $\mathrm{Ca}^{2+}$ channel surface expression has produced conflicting results. Immunostaining of hemagglutinin-tagged $\mathrm{Ca}_{\mathrm{V}} \alpha_{1} 1.2 / \beta 3$ expressed in HEK293 cells indicates that both $\mathrm{Kir} / \mathrm{Gem}$ and Rem2 reduce $\mathrm{Ca}^{2+}$ channel 
expression at the cell surface (Béguin et al., 2001, 2005). Additionally, overexpression of Kir/Gem in cardiomyocytes resulted in marked reduction of the gating currents arising from L-type $\mathrm{Ca}^{2+}$ channels, indicating a reduced expression of functional channels at the cell surface (Murata et al., 2004). In contrast, Rem 2 overexpression had little effect on the cell surface density of endogenous L-type $\mathrm{Ca}^{2+}$ channels in insulin-secreting cells as determined by surface biotinylation (Finlin et al., 2005). Thus, the mechanism(s) of Rem2-mediated downregulation of L-type $\mathrm{Ca}^{2+}$ channels remains controversial.

Among the RGK family, Rem 2 is the only member abundantly expressed in neuronal tissues (Finlin et al., 2000). Although recent studies have examined the effects of Rem 2 on L-type $\mathrm{Ca}^{2+}$ channels in clonal cells lines, the effects of Rem 2 on $\mathrm{N}$-type $\mathrm{Ca}^{2+}$ channels natively expressed in mammalian neurons is unknown. We have thus examined modulation by Rem 2 of endogenous voltage-dependent $\mathrm{Ca}^{2+}$ channels in rat sympathetic and sensory neurons and tsA201 cells stably expressing an $\mathrm{N}$-type $\mathrm{Ca}^{2+}$ channel of defined composition $\left(\mathrm{Ca}_{\mathrm{v}} \alpha_{1} 2.2 / \beta 3 / \alpha_{2} \delta\right)$.

\section{Materials and Methods}

All experiments were approved by the Institutional Animal Care and Use Committee.

cDNA plasmid constructs and recombinant adenoviruses. Most of our experiments were based on the originally deposited rat Rem 2 sequence (GenBank accession number AF084464) (Finlin et al., 2000). During the course of these experiments, examination of expressed sequence tags and genomic DNA sequences across several species (while searching for alternative splicing variants) revealed two in-frame ATGs upstream of the start codon assigned in AF084464. The longest predicted open reading frame (deposited as GenBank accession number AY916790) encodes an additional 69 residues at the $\mathrm{N}$ terminus. The open reading frame assigned in AF084464 likely arose from a sequencing error rather than representing a genuine alternative splice variant. Recently, this discrepancy was noted by two other groups (Béguin et al., 2005; Finlin et al., 2005). To maintain consistency with the nomenclature used in recent publications, we term the shorter construct Rem2t (truncated; equivalent to Rem $2 \mathrm{~N} \Delta 69$ by Finlin et al., 2005) and the longer sequence Rem 2 .

The coding sequences of Rem $2 \mathrm{t}$ and Rem 2 were amplified from mRNA of rat dorsal root ganglia (DRGs) by reverse transcription-PCR, and the resulting PCR products were ligated into the multiple cloning region of mammalian expression vectors, including pCI (Promega, Madison, WI), pEGFP-C1, and pEGFP-N1 (BD Biosciences Clontech, Mountain View, CA). The forward primer was designed such that the start codon was under the optimal context for translational initiation (Kozak, 1999). All truncation, green fluorescent protein (GFP)-fusion, and point mutant constructs were prepared using PCR-based methods. Fidelity of the PCR products was confirmed by automated DNA sequencing. Adenoviruses expressing GFP (Ad-GFP) or GFP-Rem $2 t$ were generated using the AdEasy system (He et al., 1998; Chen et al., 2004a).

Cell cultures. Single superior cervical ganglion (SCG) neurons were isolated from 10- to 14-week-old male Wistar rats as described previously (Ikeda, 2004). Briefly, after dissection, the ganglia were desheathed, cut into small pieces, and incubated with $0.7 \mathrm{mg} / \mathrm{ml}$ collagenase type D (Roche Molecular Biochemicals, Indianapolis, IN), $0.4 \mathrm{mg} / \mathrm{ml}$ trypsin (Worthington, Lakewood, NJ), and $0.1 \mathrm{mg} / \mathrm{ml}$ DNase 1, type IV, (Sigma, St. Louis, MO) in minimal essential medium (MEM) saturated with 5\% $\mathrm{CO}_{2} / 95 \% \mathrm{O}_{2}$ at $35^{\circ} \mathrm{C}$ for $1 \mathrm{~h}$. Thereafter, cells were dissociated by vigorous shaking of the flask. After centrifugation twice at $50 \times \mathrm{g}$, the dispersed neurons were resuspended in MEM containing $10 \%$ fetal bovine serum, $1 \%$ glutamine, and $1 \%$ penicillin-streptomycin solution (all from Invitrogen, Carlsbad, CA). Neurons were then plated into polystyrene tissue culture dishes coated with poly-L-lysine and stored in a humidified atmosphere containing $5 \% \mathrm{CO}_{2}$ in air at $37^{\circ} \mathrm{C}$. Single DRG neurons were isolated from 1- to 2-week-old Sprague Dawley rats using essentially the same procedure except that the trypsin concentration was reduced to 0.1 $\mathrm{mg} / \mathrm{ml}$. Hippocampal neurons isolated from newborn Sprague Dawley rats were cultured essentially as described previously (Chen and Lambert, 2000 ) except that neurons were grown on glass bottom dishes coated with poly-D-lysine $(0.1 \mathrm{mg} / \mathrm{ml})$. HEK293 cells and COS-7 cells were cultured in growth media as recommended by the provider (American Type Culture Collection, Manassas, VA). A tsA201 cell line stably expressing $\mathrm{Ca}_{\mathrm{v}} \alpha_{1} 2.2 / \beta 3 / \alpha_{2} \delta$ (a gift from Dr. Diane Lipscombe, Brown University, Providence, RI) was maintained as described previously (Lin et al., 2004).

Intranuclear injection, transfection, and adenoviral infection. cDNA constructs $(50-100 \mathrm{ng} / \mu \mathrm{l}$ in $10 \mathrm{~mm}$ Tris, $\mathrm{pH} 8)$ were injected into the nucleus of SCG neurons $4-8 \mathrm{~h}$ after cell isolation with an Eppendorf (Brinkmann Instruments, Westbury, NY) FemtoJet microinjector and 5171 micromanipulator (Ikeda, 2004). When necessary, neurons were coinjected with pEGFP-N1 $(5 \mathrm{ng} / \mu \mathrm{l})$ to facilitate later identification of successfully injected cells. SCG neurons expressing GFP were used for whole-cell patch-clamp recordings within $21-28 \mathrm{~h}$ after injection. Transfection of mammalian cell lines and hippocampal neurons ( 1 week in culture) was mediated by Lipofectamine 2000 following the instructions of the manufacturer (Invitrogen). DRG neurons were infected 6-12 h after isolation by adding $1-3 \times 10^{8}$ infectious units (diluted in MEM) of recombinant adenoviruses to each $35 \mathrm{~mm}$ dish, followed by replacement of the culture medium after $12 \mathrm{~h}$. Recording was made 36-48 h after infection. SCG neurons were infected $2 \mathrm{~h}$ after isolation by adding $4 \times$ $10^{8}$ infectious units of Ad-GFP.

Electrophysiology. Whole-cell currents were recorded with a patchclamp amplifier (Axopatch 200B; Axon Instruments, Union City, CA) at room temperature $\left(21-24^{\circ} \mathrm{C}\right)$ using the conventional whole-cell variant of the patch-clamp technique (Hamill et al., 1981). For recording $\mathrm{Ca}^{2+}$ current $\left(I_{\mathrm{Ca}}\right)$, patch electrodes were pulled from borosilicate glass capillaries (Corning 7052; Garner Glass, Claremont, CA) on a P-97 FlamingBrown micropipette puller (Sutter Instruments, Novato, CA), fire polished on a microforge, and filled with a solution containing the following (in mM): $120 \mathrm{~N}$-methyl-D-glucamine, 20 tetraethylammonium-OH, 10 HEPES, 11 EGTA, $1 \mathrm{CaCl}_{2}$, 14 Tris-creatine phosphate, $4 \mathrm{MgATP}$, and $0.3 \mathrm{Na}_{2} \mathrm{GTP}, \mathrm{pH}$ adjusted to 7.24 with methanesulfonic acid and $\mathrm{HCl}(20$ $\mathrm{mm}$ final $\left.\left[\mathrm{Cl}^{-}\right]\right)$. In some experiments, as specified, GTP was replaced with $2 \mathrm{~mm}$ GDP- $\beta$-S. Pipette resistances ranged from 1 to $3 \mathrm{M} \Omega$, yielding uncompensated series resistances of 2-6 M $\Omega$. Electronic series resistance compensation of $80 \%$ was used in all recordings. For recording $I_{\mathrm{Ca}}$ from SCG neurons and tsA201 cells stably expressing $\mathrm{Ca}_{\mathrm{v}} \alpha_{1} 2.2 / \beta 3 / \alpha_{2} \delta$, the external solution consisted of $145 \mathrm{~mm}$ tetraethylammonium methanesulfonate, $10 \mathrm{~mm}$ HEPES, $15 \mathrm{~mm}$ glucose, $10 \mathrm{~mm} \mathrm{CaCl}_{2}$, and $300 \mathrm{~nm}$ tetrodotoxin, $\mathrm{pH} 7.35,320 \mathrm{mOsm} / \mathrm{kg}$. Unless indicated otherwise, $I_{\mathrm{Ca}}$ recorded from SCG neurons and tsA201 cells was evoked by a double-pulse voltage protocol (Elmslie et al., 1990) consisting of an initial $20 \mathrm{~ms}$ test pulse ("prepulse") stepped from the holding potential of $-80 \mathrm{mV}$, a 50 ms depolarizing conditioning pulse to $+80 \mathrm{mV}$, and a subsequent $20 \mathrm{~ms}$ test pulse to $+10 \mathrm{mV}$ ("postpulse"). $I_{\mathrm{Ca}}$ density was determined from the amplitude of $I_{\mathrm{Ca}}$ evoked at the midpoint of the prepulse normalized to the cell capacitance. For recording $I_{\mathrm{Ca}}$ from DRG neurons, the bathing solution $\mathrm{CaCl}_{2}$ was reduced to $5 \mathrm{~mm}$, and the HEPES was increased by an identical amount. Low-voltage-activated (LVA) $I_{\mathrm{Ca}}$ from DRG neurons was evoked at $-40 \mathrm{mV}$ from a holding potential of $-80 \mathrm{mV}$. Highvoltage-activated $I_{\mathrm{Ca}}$ from DRG neurons was evoked at $+10 \mathrm{mV}$. Voltage protocol generation and data acquisition were performed using custom data-acquisition software on a Macintosh G4 computer (Apple Computers, Cupertino, CA) with an ITC-18 interface board (InstruTech, Port Washington, NY). $I_{\mathrm{Ca}}$ traces were low-pass filtered at $2-5 \mathrm{kHz}$ and digitized at $10 \mathrm{kHz}$.

$\left.{ }^{125} I\right]$ Tyr $^{22}$ - $\omega$-conotoxin GVIA binding assay. Unless indicated otherwise, $2 \times 10^{5}$ (per well) tsA201 cells stably expressing a high density of $\mathrm{Ca}_{\mathrm{v}} \alpha_{1} 2.2 / \beta 3 / \alpha_{2} \delta$ (N-type) $\mathrm{Ca}^{2+}$ channels (Lin et al., 2004) were cultured overnight in a 24 -well plate (Visiplate-24 TC; PerkinElmer, Wellesley, MA) precoated with rat tail collagen. Plasmid constructs expressing GFP, GFP-Rem 2t, and GFP-Rem 2 were then transfected for $\sim 26 \mathrm{~h}$ using Lipofectamine 2000 following the instructions of the manufacturer (Invitrogen). The culture medium was removed from each well, and the cells were rinsed once with PBS buffer containing $0.3 \%$ bovine serum albumin (supplemented with $1 \mathrm{mM} \mathrm{Ca}^{2+}$ and $1 \mathrm{mM} \mathrm{Mg}^{2+}$ to prevent cell detachment). Cells were then incubated with $\left[{ }^{125} \mathrm{I}\right] \mathrm{Tyr}^{22}$ - $\omega$-conotoxin GVIA (1 
nM, $300 \mu \mathrm{l}$ per well, $2200 \mathrm{Ci} / \mathrm{mmol}$; PerkinElmer), a specific N-type $\mathrm{Ca}^{2+}$ channel antagonist (Terlau and Olivera, 2004) for 45 min at room temperature. To remove the unbound radioactive ligand, cells were washed gently with the above-modified PBS buffer (eight times for $5 \mathrm{~min}$ ). One milliliter of Optiphase Supermix (1200-439; PerkinElmer) was added to each well, and the bound ligand was measured from the radioactivity detected in a microplate scintillation counter (MicroBeta Trilux LSC; PerkinElmer). Nonspecific binding was $<5 \%$ as calculated from the radioactivity in control wells containing a comparable number of HEK293 cells.

Statistical analysis. Numerical values are expressed as mean \pm SEM. Statistical comparisons were made by using Student's $t$ test or ANOVA, followed by Dunnett's test as appropriate. The differences were considered significant if $p<0.05$.

\section{Results}

Heterologous expression of Rem2

nearly abolishes $I_{\mathrm{Ca}}$ in adult rat

sympathetic neurons within $\sim 24 \mathrm{~h}$

To examine the effect of Rem 2 on endogenous neuronal $\mathrm{Ca}^{2+}$ channels, we expressed Rem 2 cDNA constructs in adult rat sympathetic neurons derived from the SCG. The composition of $I_{\mathrm{Ca}}$ in these neurons is relatively homogenous arising primarily from N-type $\left(\mathrm{Ca}_{\mathrm{v}} 2.2\right) \mathrm{Ca}^{2+}$ channels (Ikeda, 1991). Representative traces of $I_{\mathrm{Ca}}$ recorded from a control (uninjected) neuron and a neuron injected with Rem 2 cDNA are depicted in Figure $1 A$. $\mathrm{Ca}^{2+}$ currents were evoked from a holding potential of $-80 \mathrm{mV}$ with $70 \mathrm{~ms}$ test pulses to the indicated voltages. Recordings made 21-26 h after cDNA injection revealed a dramatic decrease in $I_{\mathrm{Ca}}$ amplitude across the entire voltage range (approximately -30 to $+60 \mathrm{mV}$ ) without apparent alteration in the shape of the evoked currents. To facilitate comparisons from neurons of different size, $I_{\mathrm{Ca}}$ amplitude (measured isochronally at 10 ms after initiation of the test pulse) was normalized to membrane capacitance $\left(C_{m}\right)$ and expressed as $I_{\mathrm{Ca}}$ density (in picoamperes per picofarad). $C_{m}$ is related to cell surface area and was determined by integrating the capacitance transient produced by a $5 \mathrm{mV}$ depolarizing pulse. Mean \pm SEM current density-voltage $(I-V)$ relationships from control neurons and neurons expressing Rem 2 or Rem $2 t$ are shown in Figure $1 B$. Both Rem 2 constructs produced nearly identical results, with $I_{\mathrm{Ca}}$ density being severely depressed across the entire voltage range. The effects of Rem2, Rem2t, GFP-Rem 2t, and Rem2t-GFP on peak $I_{\mathrm{Ca}}$ density (determined for a test pulse to $+10 \mathrm{mV}$ ) are summarized in Figure $1 C$. Mean peak $I_{\mathrm{Ca}}$ density in neurons

A. Uninj.

C.

E.
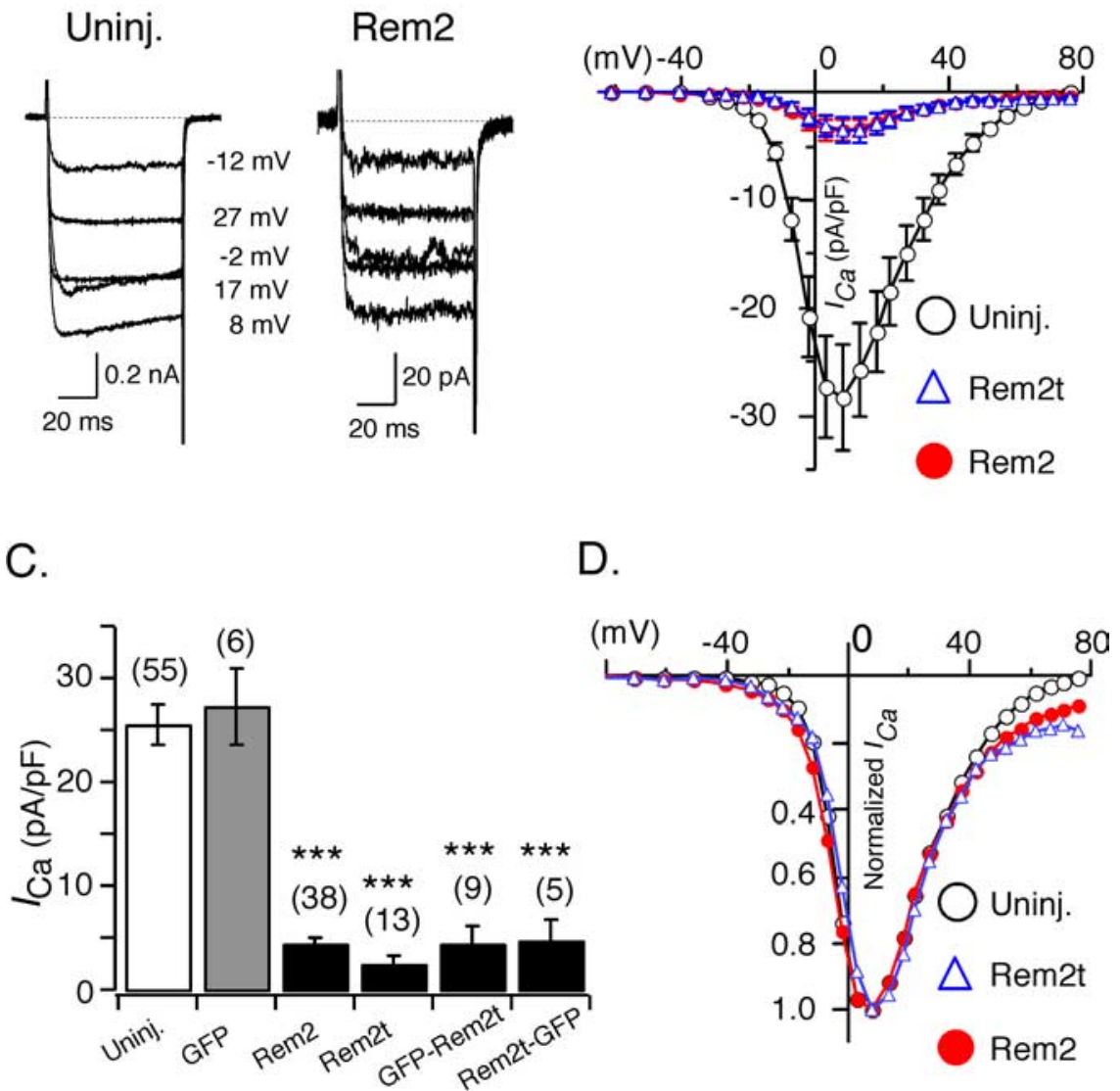

$\mathrm{F}$.
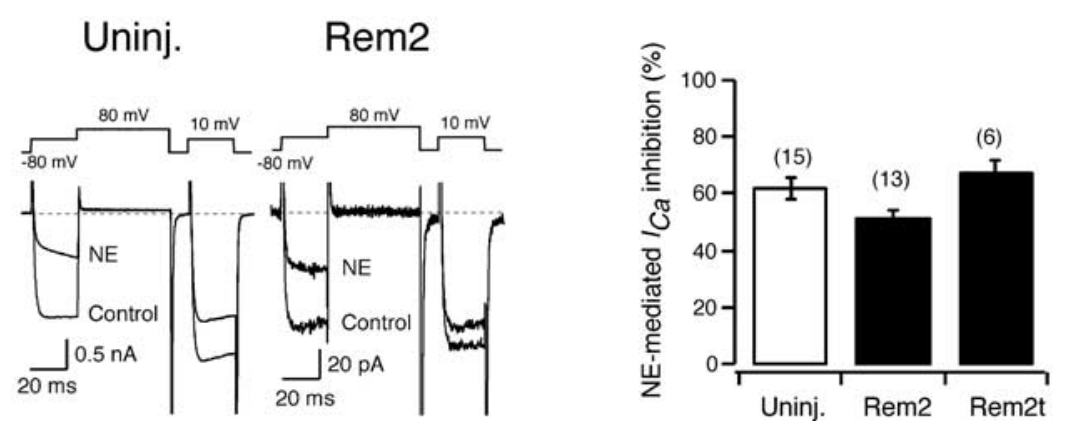

Figure 1. Effects of heterologous expression of Rem2 on N-type $\mathrm{Ca}^{2+}$ channels of sympathetic neurons. $\boldsymbol{A}$, Superimposed representative $I_{\mathrm{Ca}}$ traces recorded from a control (uninjected) neuron (left) and a neuron expressing Rem 2 (right). Expression was accomplished with nuclear microinjection (see Materials and Methods). $I_{\mathrm{Ca}_{\mathrm{a}}}$ was evoked by a $70 \mathrm{~ms}$ step to the indicated voltages from a holding potential of $-80 \mathrm{mV}$. $B$, Average $\pm \mathrm{SEM} I_{\mathrm{Ca}} I-V$ relationships for $I_{\mathrm{Ca}}$ recorded from control neurons (open circles) and neurons expressing Rem2 (filled circles) or Rem2t (open triangles). $I_{\mathrm{Ca}_{\mathrm{a}}}$ density was calculated from $I_{\mathrm{Ca}}$ amplitude at a series of test pulses normalized to cell membrane capacitance. $C$, Average $\pm \mathrm{SEM} I_{\mathrm{Ca}}$ density in control neurons (open bar) and neurons expressing GFP, Rem2, Rem2t, GFP-Rem2t, or Rem2t-GFP as indicated (filled bars). Ca $_{\text {a }}$ density was calculated from Ca $_{\text {a }}$ amplitude at a test pulse of $+10 \mathrm{mV}$ normalized to cell membrane capacitance. $\boldsymbol{D}$, The mean values from $\boldsymbol{B}$ were scaled to facilitate comparison of the current density-voltage relationship. $\boldsymbol{E}$, Superimposed $I_{\mathrm{Ca}}$ traces recorded in the absence or presence of $\mathrm{NE}$ (10 $\mu \mathrm{m}$ ) from a control neuron (left) and a neuron expressing Rem2 (right). $I_{\mathrm{Ca}}$ was evoked at $0.1 \mathrm{~Hz}$ with the voltage protocol illustrated. $\boldsymbol{F}$, Average $I_{\mathrm{Ca}_{\mathrm{a}}}$ inhibition mediated by NE in control neurons and neurons expressing Rem 2 or Rem2t. The number of neurons tested is shown in parentheses. ${ }^{* * *} p<0.001$ versus controls, ANOVA followed by Dunnett's test. Uninj., Uninjected. injected with Rem 2 or Rem $2 t$ cDNA was greatly decreased when compared with control neurons $(4.4 \pm 0.7$ and $2.4 \pm 0.8$, respectively, versus $24.2 \pm 2.1 \mathrm{pA} / \mathrm{pF} ; p<0.001$, ANOVA). Whereas expression of GFP alone had no effect on $I_{\mathrm{Ca}}$ density $(27.3 \pm 3.7$ 
A.

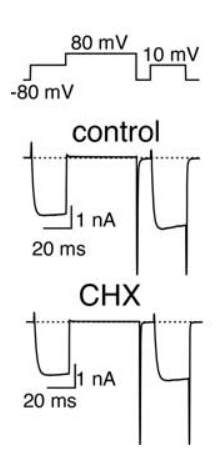

B.

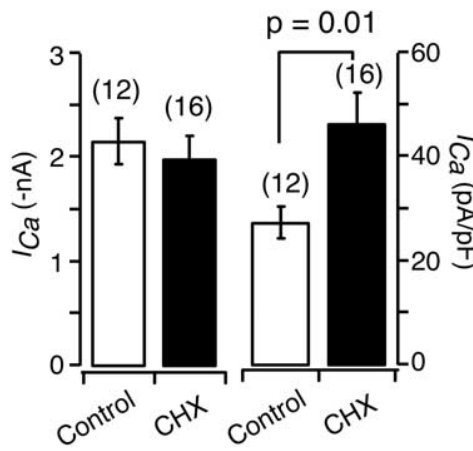

C.

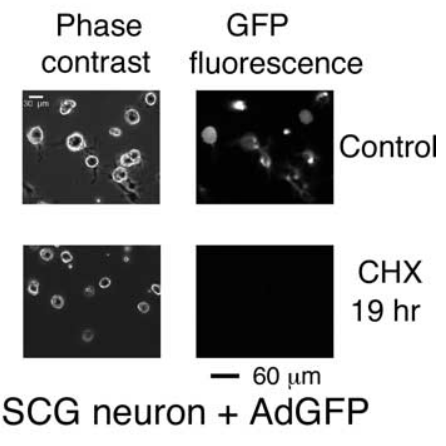

Figure 2. Treatment of sympathetic neurons with cycloheximide, a protein translation blocker, did not alter $I_{\mathrm{Ca}}$ amplitude. $\boldsymbol{A}$, Representative whole-cell $I_{\mathrm{Ca}}$ traces from a control neuron and a neuron pretreated with cycloheximide $(0.35 \mathrm{~mm})$ for $\sim 24 \mathrm{~h}$. The voltage protocol above the current traces was repeated at $0.1 \mathrm{~Hz}$. $B$, Average $\pm \mathrm{SEM} / \mathrm{Ca}_{\mathrm{a}}$ amplitude and density in control neurons (open bar) and neurons pretreated with cycloheximide (filled bar) for 22-29 h. C, Phase-contrast (left column) and fluorescent (right column) micrographs illustrating adenovirus-mediated GFP expression in control neurons (top row) and neurons treated with cycloheximide (bottom row).

$\mathrm{pA} / \mathrm{pF} ; p=0.997)$, expression of the fusion constructs GFPRem $2 \mathrm{t}$ and Rem2t-GFP significantly $(p<0.001)$ reduced $I_{\mathrm{Ca}}$ density to $4.4 \pm 1.7$ and $4.7 \pm 2.0 \mathrm{pA} / \mathrm{pF}$, respectively, indicating that fusion of GFP did not disrupt the effects of Rem $2 t$ and that a free $\mathrm{N}$ or $\mathrm{C}$ terminus was not required for inhibition of $I_{\mathrm{Ca}}$.

In 13 of 65 neurons expressing Rem2, Rem $2 t$, Rem2t-GFP, or GFP-Rem $2 \mathrm{t}, I_{\mathrm{Ca}}$ was reduced below detectable levels $(<1 \mathrm{pA} / \mathrm{pF})$. However, because a measurable residual $I_{\mathrm{Ca}}$ was seen in the majority of neurons, the question arose as to whether the residual $I_{\mathrm{Ca}}$ differed substantially from the unmodified $I_{\mathrm{Ca}}$. As shown in Figure $1 \mathrm{D}$, scaling of the mean $I_{\mathrm{Ca}}$ density data (from Fig. $1 \mathrm{~A}$ ) reveals a nearly identical relationship between $I_{\mathrm{Ca}}$ density and test pulse potential. The apparent deviation seen at very positive potentials (more than $+40 \mathrm{mV}$ ) likely results from errors introduced during leak subtraction of the very small currents in the Rem2expressing neurons. The response of the residual $I_{\mathrm{Ca}}$ to heterotrimeric G-protein-mediated modulation was also examined (Fig. $1 E, F) . \mathrm{N}$-type $\mathrm{Ca}^{2+}$ channels in sympathetic neurons are inhibited after activation of endogenous $\alpha_{2 \mathrm{~A}}$ adrenergic receptors with norepinephrine (NE) (Schofield, 1991). The modulation is mediated by the $G \beta \gamma$ subunit and defined as voltage dependent based on several distinct characteristics (Ikeda and Dunlap, 1999) as illustrated for the control $I_{\mathrm{Ca}}$ in Figure $1 E$ (left). Here, currents were evoked with a double-pulse voltage protocol (Elmslie et al., 1990) composed of two identical test pulses separated by a depolarizing conditioning pulse. In the presence of NE $(10 \mu \mathrm{M})$, the current evoked by the first pulse was reduced in amplitude and the rising phase of the current slowed (a phenomenon termed kinetic slowing). After the conditioning pulse, the current inhibition was markedly relieved and the kinetic slowing reversed. Application of NE to an Rem2-expressing neuron produced similar effects despite the large reduction in $I_{\mathrm{Ca}}$ amplitude (Fig. $1 \mathrm{E}$, right). Comparison of the mean $I_{\mathrm{Ca}}$ inhibition (determined from the first test pulse) produced by NE for the control, Rem2modified, and Rem2t-modified $I_{\mathrm{Ca}}($ Fig. $1 F)$ revealed a similar magnitude of inhibition ( $~ 50-60 \%)$.

Together, these results show that expression of Rem 2 nearly abolished N-type $I_{\mathrm{Ca}}$ in adult rat sympathetic neurons within $\sim 24$ h. Expression of Rem $2 t$ and constructs encoding GFPfusions to either terminus of the molecule produced nearly identical results. The small component of $I_{\mathrm{Ca}}$ remaining after $\sim 24 \mathrm{~h}$ has macroscopic properties similar to the total $I_{\mathrm{Ca}}$. Hence, this

component likely arises from a population of unmodified channels.

Blockade of protein translation did not replicate the effects of Rem 2 expression To determine whether the $I_{\mathrm{Ca}}$ reduction after Rem 2 expression resulted from actions on preexisting channels or interference with the synthesis of new channels, we tested the effect of blocking protein translation on $I_{\mathrm{Ca}}$ in rat SCG neurons. We reasoned that, if Rem 2 produced a reduction in $I_{\mathrm{Ca}}$ by inhibiting channel synthesis, then pretreatment of the neurons for 20-29 h with cycloheximide (CHX) (0.35 $\mathrm{mM})$, an established protein translation blocker (Lee and Hollenbeck, 2003), should produce similar results. As shown in Figure 2, $A$ and $B$, mean $I_{\mathrm{Ca}}$ amplitude was unaltered $(2.12 \pm 0.30$ vs $1.98 \pm 0.22$ $\mathrm{nA}$ in control and treated neurons, respectively) by CHX pretreatment. When the data were normalized to $C_{m}$, CHX treatment actually produced an increase, rather than a decrease, in mean $I_{\mathrm{Ca}}$ density (Fig. $2 \mathrm{~B}$, right). Although these results might suggest an increase in the population of $\mathrm{Ca}^{2+}$ channels at the plasma membrane, the increased $I_{\mathrm{Ca}}$ density resulted from a decrease in $C_{m}(47.2 \pm 4.3$ vs $78.3 \pm 3.7 \mathrm{pF}$ for $\mathrm{CHX}-$ treated and control neurons, respectively; $p<0.001$, unpaired $t$ test) rather than an increase in $I_{\mathrm{Ca}}$ amplitude. Consistent with this finding, CHX appeared to decrease the diameter of neuron somata (Fig. 2C, phase contrast images), although this was not examined in detail. As a positive control for CHX treatment, adenovirus-mediated GFP expression in neurons was monitored by epifluorescence microscopy. As shown in Figure 2C, $22 \mathrm{~h}$ after infection with Ad-GFP $\left(4 \times 10^{8}\right.$ infectious units/ml), GFP fluorescence was detected in both neurons and glia in control but not CTX-treated cells. To ensure that adenoviral entry into cells was not encumbered, Ad-GFP lysate was added to the neuronal culture for $3 \mathrm{~h}$ before initiating CHX treatment.

Because the amplitude of $I_{\mathrm{Ca}}$ in SCG neurons was not altered after block of protein translation for $\sim 24 \mathrm{~h}$, we conclude that $\mathrm{Ca}^{2+}$ channel turnover is relatively slow within the time course of these experiments. Therefore, the ability of Rem 2 to decrease $I_{\mathrm{Ca}}$ density likely arises from effects on preexisting $\mathrm{N}$-type $\mathrm{Ca}^{2+}$ channels rather than alterations in channel synthesis as has been seen for other molecules (e.g., $\mathrm{Ca}_{\mathrm{v}} \gamma_{7}$ ) (Moss et al., 2002).

\section{Domains of Rem 2 important for cellular localization and $\mathrm{Ca}^{2+}$ channel downregulation}

Rem 2 directly interacts with $\mathrm{Ca}_{\mathrm{v}} \beta$ subunits as shown by coimmunoprecipitation and GST pull-down assays (Béguin et al., 2005; Finlin et al., 2005). If this association is required for the downregulation of preexisting functional $\mathrm{Ca}^{2+}$ channels, we anticipated that Rem 2 would be enriched at the plasma membrane. To examine this notion, GFP fusion constructs were heterologously expressed in clonal cell lines and primary neuronal cultures. Expression of GFP-Rem2t and Rem2t-GFP in cultured rat hippocampal neurons resulted in a "rim-type" fluorescence pattern consistent with enrichment at the plasma membrane (Fig. 3, top row). However, a similar fluorescence pattern was seen in COS-7 cells (Fig. 3, bottom row), a cell line shown to be devoid of $\mathrm{Ca}_{\mathrm{v}}$ subunits (Berrow et al., 1997). Therefore, trafficking of Rem $2 t$ to the plasma membrane was not dependent on $\mathrm{Ca}^{2+}$ channel sub- 
units and likely arose from an intrinsic affinity of Rem $2 t$ for the plasma membrane.

To define the role of various Rem 2 domains in plasma membrane targeting and downregulation of $\mathrm{Ca}^{2+}$ channels, a series of truncation constructs, based around the central Ras homology domain, were prepared and expressed in SCG neurons by intranuclear injection (Fig. $4 \mathrm{~A}$, left). Deletion of the N-terminal domain $(\operatorname{Rem} 2 \Delta \mathrm{N})$ altered neither the fluorescence pattern of GFP-Rem2t in HEK293 cells and SCG neurons nor the effect of Rem 2 on $I_{\mathrm{Ca}}$ density. As shown in Figure 4, both GFP-Rem $2 \mathrm{t}$ and GFP-Rem $2 \Delta \mathrm{N}$ were enriched at the plasma membrane when heterologously expressed in HEK293 cells and SCG neurons. In addition, $I_{\mathrm{Ca}}$ density was dramatically reduced in SCG neurons expressing Rem $2 \Delta \mathrm{N}(1.65 \pm 0.79 \mathrm{pA} / \mathrm{pF})$ or GFP-Rem $2 \Delta \mathrm{N}(2.46 \pm$ $0.65 \mathrm{pA} / \mathrm{pF}$ ) when compared with control neurons (Fig. $4 A$, open bar). In contrast, deletion of the C-terminal domain (GFPRem $2 \mathrm{t} \Delta \mathrm{C}$ ) not only confined the truncated protein to the cytoplasm, consistent with a previous report (Finlin et al., 2000), but also rendered both Rem $2 \mathrm{t} \Delta \mathrm{C}$ and GFP-Rem $2 \mathrm{t} \Delta \mathrm{C}$ ineffective in modulating $I_{\mathrm{Ca}}$ density in SCG neurons $(30.4 \pm 6.2$ and $26.7 \pm$ $3.1 \mathrm{pA} / \mathrm{pF}$, respectively). Like GFP-Rem $2 \mathrm{t} \Delta \mathrm{C}$, the Ras-homology core domain alone (GFP-Rem2core) displayed a cytosolic fluorescence pattern and was ineffective at altering $I_{\mathrm{Ca}}$ density $(25.7 \pm$ $2.6 \mathrm{pA} / \mathrm{pF}$ ). The results of these experiments implicate the $\mathrm{C}$ terminus in targeting Rem 2 to the plasma membrane. To substantiate this idea, soluble GFP was fused to the C-terminal domain of Rem2 (GFP-Rem2ct). Expression of GFP-Rem2ct resulted in a rim-type fluorescence pattern consistent with the idea that the Rem2ct possesses intrinsic affinity for the plasma membrane. However, $I_{\mathrm{Ca}}$ density in neurons expressing GFP-Rem2ct was comparable with control neurons. Thus, the core domain may be responsible for $\mathrm{Ca}^{2+}$ channel downregulation but is unable to function in the absence of appropriate plasma membrane targeting.

To further examine this hypothesis, the Rem 2 core domain was fused to the $\mathrm{C}$ terminus (23 residues) of $\mathrm{K}$-Ras4B, an extensively studied membrane-targeting domain consisting of a polybasic region and a farnesylation motif (Prior and Hancock, 2001). The resulting construct and GFP adduct were termed Rem 2 core-F+ and GFP-Rem 2 core-F+, respectively. Expression of the Rem 2 core-F+ constructs in SCG neurons resulted in a reduction of $I_{\mathrm{Ca}}$ density $(8.46 \pm 1.2$ and $5.85 \pm 1.1 \mathrm{pA} / \mathrm{pF}$, respectively; $p<0.001$ when compared with $I_{\mathrm{Ca}}$ density from control neurons). Consistent with the rescue of function, the fluorescence pattern of GFP-Rem2core-F+ expressed in HEK293 cells and SCG neurons was similar to that of GFP-Rem2t (i.e., plasma membrane enriched). A complementary experiment was undertaken in which the first 10 residues of the heterotrimeric G-protein $\alpha$ subunit, $\mathrm{G} \alpha_{\mathrm{i} 1}$, was fused to the $\mathrm{N}$ terminus of Rem $2 \mathrm{t} \Delta \mathrm{C}$ or GFP-Rem $2 \mathrm{t} \Delta \mathrm{C}$ (termed Gi1-Rem $2 \mathrm{t} \Delta \mathrm{C}$ and Gi1GFP-Rem $2 \mathrm{t} \Delta \mathrm{C}$, respectively). The $\mathrm{N}$ terminus of $\mathrm{G} \alpha_{\mathrm{i} 1}$ contains both myristoylation and palmitoylation motifs (Fivaz and Meyer, 2003) that efficiently targets fusion proteins to the plasma membrane. As expected, the fluorescence pattern of Gi1-GFPRem $2 \mathrm{t} \Delta \mathrm{C}$ expressed in HEK293 cells and SCG neurons revealed apparent plasma membrane enrichment. However, $I_{\mathrm{Ca}}$ density in neurons expressing Gi1-Rem $2 \mathrm{t} \Delta \mathrm{C}$ was comparable with control neurons $(18.7 \pm 3.0$ vs $24.6 \pm 1.67 \mathrm{pA} / \mathrm{pF} ; p=0.42$, ANOVA), demonstrating that plasma membrane targeting, although necessary, was not the sole factor in conferring function activity to the Rem 2 core domain. Similarly, $I_{\mathrm{Ca}}$ density in neurons expressing Gi1-GFP-Rem2t $\Delta \mathrm{C}$ was also not significantly different from control neurons $(19.0 \pm 4.4$ vs $25.9 \pm 2.0 \mathrm{pA} / \mathrm{pF} ; p=0.23$, ANOVA).
GFP-Rem2t
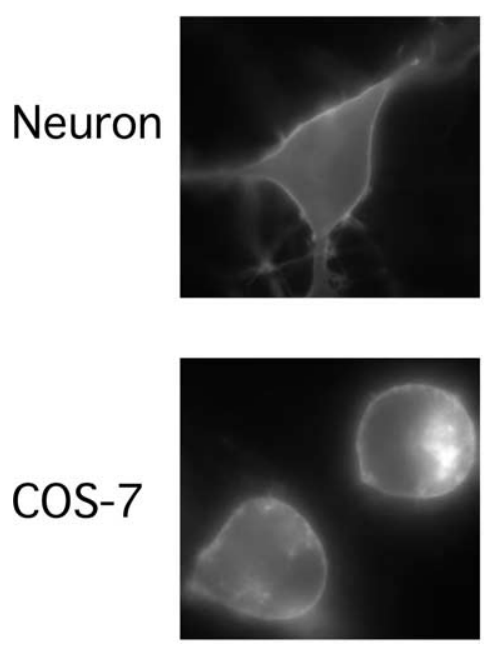

Rem2t-GFP
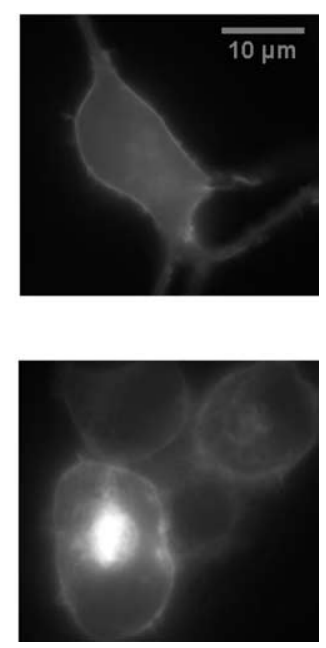

Figure 3. Heterologously expressed Rem2 is enriched at the plasma membrane in hippocampal neurons and COS-7 cells. Fluorescent micrographs were taken from hippocampal neurons (top row) and COS-7 cells (bottom row) $\sim 24 \mathrm{~h}$ after transfection of CDNA constructs encoding GFP-Rem2t (left column) or Rem2t-GFP (right column). To facilitate the visualization of GFP fluorescence at plasma membrane areas, COS-7 cells were briefly treated with PBS containing trypsin-EDTA to cause cell rounding.

From these results, we propose that the Ras homology core domain of Rem 2 contains the elements necessary for the observed decrease in $\mathrm{N}$-type $I_{\mathrm{Ca}}$ density. However, to be effective, the Rem 2 core domain must be targeted to the plasma membrane by motifs in the $\mathrm{C}$, but not the $\mathrm{N}$, terminus.

\section{Rem 2 effects may be independent of GTP/ $\mathrm{Mg}^{2+}$ binding}

Small GTP binding proteins are inactive in the GDP-bound form, become active after release of GDP and binding of GTP [a process stimulated by guanine nucleotide exchange factors (GEFs)], and return to the inactive state when GTP is hydrolyzed to GDP by the intrinsic GTPase activity of small GTP binding proteins, a process accelerated by GAPs (Takai et al., 2001). However, because Rem2 (as well as other RGK family proteins) has several nonconservative amino acid substitutions within regions involved in GTP binding and hydrolysis (Finlin et al., 2000), we designed a series of experiments to examine whether the activity of Rem 2 conforms to the canonical small G-protein cycle.

The S17N mutation interferes with GTP and $\mathrm{Mg}^{2+}$ binding, thereby rendering the Ras protein ineffective (Feig, 1999). Serine 17 is located within the so-called G1 domain (Bourne et al., 1991), a region perfectly conserved in Rem2 (Finlin et al., 2000), thus allowing unambiguous assignment of the cognate residue (S129). Unexpectedly, the mean $I_{\mathrm{Ca}}$ density in SCG neurons expressing Rem2t-S129N or GFP-Rem2t-S129N (Fig. 5A) was markedly reduced $(6.74 \pm 1.4$ and $8.88 \pm 0.91 \mathrm{pA} / \mathrm{pF}$, respectively) compared with control neurons $(26.9 \pm 2.9 \mathrm{pA} / \mathrm{pF} ; p<$ 0.001, ANOVA). These results suggest that GTP/ $\mathrm{Mg}^{2+}$ binding to Rem 2 may not be required for the Rem 2 -mediated decrease in $I_{\mathrm{Ca}}$ density observed in SCG neurons. We also observed that GFPRem2t-S129N, when expressed in COS-7 cells, was excluded from the nucleus, whereas GFP-Rem $2 t$ was distributed throughout the cell (Fig. $5 B$ ). It should be noted that, with flat cells like COS-7, conventional wide-field fluorescence microscopy is not well suited to distinguish fluorescence originating from the plasma membrane area versus the cytoplasm. Because Ras S17N binds Ras-specific GEFs with higher affinity than wild-type Ras 
A.

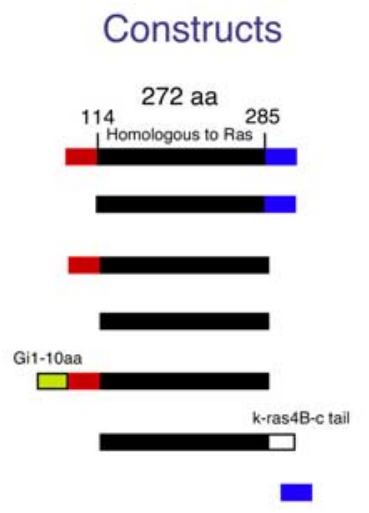

B.

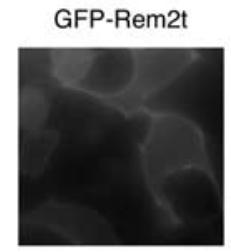

Gi1-GFP-Rem2t $\Delta C$

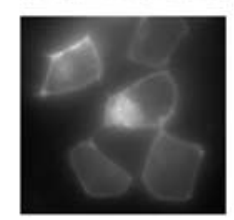

C.

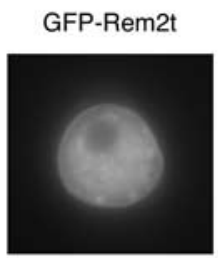

Gi1-GFP-Rem2t $\Delta C$

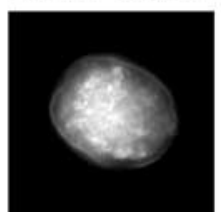

SCG neurons
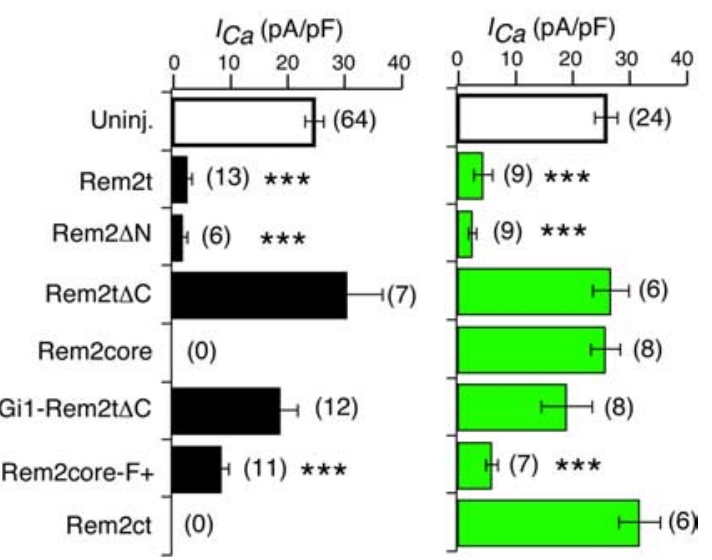

GFP-fusion constructs

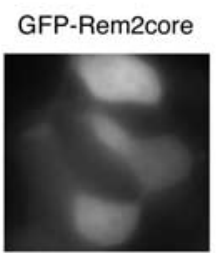

GFP

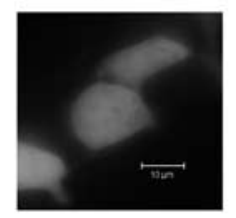

GFP-Rem2core

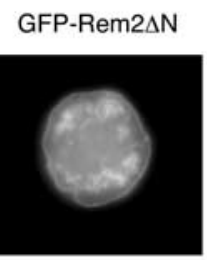

GFP-Rem2core-F+

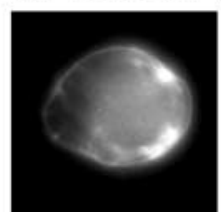

GFP-Rem2t $\Delta C$

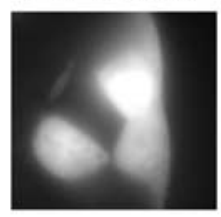

GFP-Rem2ct

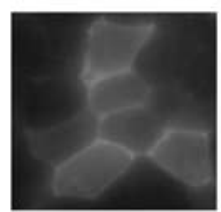

GFP-Rem2t $\Delta C$

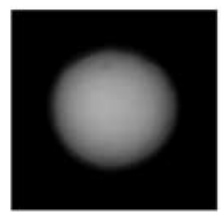

GFP-Rem2ct

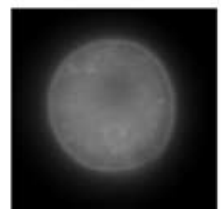

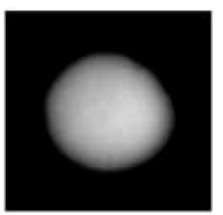

GFP

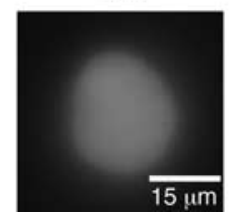

Figure 4. The structure-function relationship of Rem2. $A$, Average $\pm \mathrm{SEM} / \mathrm{Ca}$ density in uninjected neurons (open bar) and neurons injected (filled bars) with CDNA constructs encoding one of the truncated or recombinant Rem2 (middle panel) as illustrated in the schematic diagram (left panel). Average $\pm S E M I_{C a}$ density in uninjected neurons (open bar) and neurons injected (filled bars) with the corresponding GFP-fusion CDNA constructs were summarized in the right panel. $I_{C_{a}}$ density was calculated from $I_{C_{a}}$ amplitude at a test pulse of $+10 \mathrm{mV}$ normalized to cell membrane capacitance. ${ }^{* *} p<0.001$ versus control neurons, ANOVA. $\boldsymbol{B}$, Fluorescent micrographs were taken from HEK293 cells $\sim 24 \mathrm{~h}$ after transfection with the cDNA construct as indicated above each graph. C, Fluorescent micrographs were taken from sympathetic neurons $\sim 20 \mathrm{~h}$ after intranuclear injection with the CDNA constructas indicated above each graph. Gi1-10aa, The first 10 residues of $\mathrm{G} \alpha_{\mathrm{i} i}$; $\mathrm{K}$-ras $4 \mathrm{~B}$-c-tail, the last 23 residues at the $\mathrm{C}$-end of $\mathrm{K}$-ras $4 \mathrm{~B}$; Uninj., uninjected.

(Feig, 1999), we speculate that Rem2t S129N might form a tight complex with a unique GEF and thus be excluded from the nucleus as a consequence of an increased effective mass. If this is the case, then the Rem2t-S129N/GEF complex was apparently still effective in reducing $I_{\mathrm{Ca}}$ density.

Because the function of the Rem2tS129N mutation relies on extrapolation from a cognate mutation in Ras, we performed two additional experiments to explore a potential role for GTP-binding in the actions of Rem2. As shown in Figure $5 C$, when GTP $(0.3 \mathrm{~mm})$ was included in the patch pipette solution, application of NE $(10 \mu \mathrm{M})$ to SCG neurons repeatedly inhibited $I_{\mathrm{Ca}}$ in a voltage-dependent manner (Ikeda and Dunlap, 1999). Replacement of GTP with the hydrolysis-resistant GDP analog GDP- $\beta$-S ( $2 \mathrm{~mm}$ ) resulted in an attenuation of NE-mediated inhibition within $5 \mathrm{~min}$ and abolition within $10 \mathrm{~min}$ (Schofield, 1991). These results suggest that GDP- $\beta$-S replaces the cellular guanine nucleotide, thereby locking heterotrimeric G-proteins in an inactive state. Dialysis of neurons with GDP- $\beta$-S for 10-20 $\mathrm{min}$, however, was unable to acutely rescue the $I_{\mathrm{Ca}}$ amplitude from the attenuated state produced by heterologously expressing Rem $2 \mathrm{t}$ or Rem 2 (Fig. $5 D, E)$. If we assume that dialysis with GDP- $\beta$-S produces effects on Rem 2 similar to those produced on heterotrimeric G-protein $\alpha$ subunits and Kir/Gem (Béguin et al., 2001), then these data provide additional evidence that GTP binding is not a requisite for the functional effects of Rem2.

Finally, we tested whether Rem 2 might be inactive when cells were cultured in serum-free medium. The rationale for the experiment derived from the observation that Ras family proteins are often activated by extracellular factors that couple to receptor tyrosine kinases (Takai et al., 2001). $I_{\mathrm{Ca}}$ density determined from SCG neurons expressing Rem $2 t$ and deprived of serum for at least $7 \mathrm{~h}$ before the initiation of whole-cell recording was still dramatically reduced when compared with the $I_{\mathrm{Ca}}$ density of control neurons cultured under the same condition $(1.73 \pm 0.78$ vs $29.0 \pm$ $9.32 \mathrm{pA} / \mathrm{pF} ; n=5 ; p<0.05$, unpaired $t$ test).

Specificity of Rem 2 for high-voltageactivated $\mathrm{Ca}^{2+}$ channels

The interaction of RGK proteins with the $\mathrm{Ca}_{\mathrm{V}} \beta$ subunit is believed to underlie the functional effects of these proteins on $\mathrm{Ca}^{2+}$ channel function. To examine this hypothesis, the ability of Rem 2 to modulate endogenous voltage-activated $\mathrm{Ca}^{2+}$ channels in primary sensory neurons of DRGs was examined. Unlike SCG neurons, DRG neurons express both LVA and HVA Ca ${ }^{2+}$ channels (Fedulova et al., 1985; Kostyuk et al., 1988; Regan et al., 1991; Mintz et al., 1992; Yusaf et al., 2001). Because large functional T-type currents are recorded from cells expressing only the $\mathrm{Ca}_{\mathrm{V}} \mathrm{a}_{1} 3$.x subunit, it is assumed that 
endogenous LVA $\mathrm{Ca}^{2+}$ channels neither require nor associate with $\mathrm{Ca}_{\mathrm{V}} \beta$ subunits (Perez-Reyes, 2002). Given these assumptions, one would predict differential modulation of HVA versus LVA Ca ${ }^{2+}$ currents after Rem 2 expression.

To separate $I_{\mathrm{Ca}}$ components arising from LVA and $\mathrm{HVACa}^{2+}$ channels, a voltage protocol (Chen and Ikeda, 2004) consisting of $30 \mathrm{~ms}$ test pulses to -40 and $+10 \mathrm{mV}$ evoked from a holding potential of $-80 \mathrm{mV}$ was used (Fig. $6 \mathrm{~A}$, top). The test pulses were separated by a $50 \mathrm{~ms}$ pulse to $-60 \mathrm{mV}$, which served to inactivate the majority of $\mathrm{LVA} \mathrm{Ca}^{2+}$ channels. With this voltage protocol, $I_{\mathrm{Ca}}$ evoked at $-40 \mathrm{mV}$ should arise primarily from $\mathrm{LVA} \mathrm{Ca}^{2+}$ channels because few HVA Ca ${ }^{2+}$ channels are activated near this voltage. Conversely, $I_{\mathrm{Ca}}$ recorded during the $+10 \mathrm{mV}$ test pulse is highly enriched in the HVA current component, although a small fraction may arise from a population of $\mathrm{LVA} \mathrm{Ca}^{2+}$ channels that have not undergone inactivation. As shown in Figure $6 \mathrm{~A}$, the composition of $I_{\mathrm{Ca}}$ in the DRG neuron population was heterogeneous (Fig. $6 A$, left vs right). $I_{\mathrm{Ca}}$ recorded from DRG neurons 36-48 h after infection with recombinant Ad-GFP consistently showed a high density of HVA $\mathrm{Ca}^{2+}$ current, whereas the LVA current component was highly variable. To facilitate analysis, DRG neurons were divided into two groups: one having a large $(>15 \mathrm{pA} / \mathrm{pF})$ LVA $I_{\mathrm{Ca}}$ component and the other displaying a small LVA $I_{\mathrm{Ca}}$ component $(<3.5 \mathrm{pA} / \mathrm{pF})$. As shown in Figure 6, HVA $I_{\mathrm{Ca}}$ recorded from DRG neurons $36-48 \mathrm{~h}$ after infection with adenovirus expressing GFP-Rem $2 t$ was dramatically reduced, whereas the amplitudes of LVA-type current varied from cell to cell. Within the first group, although the amplitudes of LVA-type $I_{\mathrm{Ca}}$ were comparable in neurons expressing GFP and GFP-Rem $2 \mathrm{t}(29.0 \pm 3.8$ and $32.2 \pm 5.3 \mathrm{pA} / \mathrm{pF}$, respectively; $p=$ 0.54 , unpaired $t$ test), HVA $I_{C a}$ was markedly reduced $(27.6 \pm 2.8$ and $6.89 \pm 1.0 \mathrm{pA} / \mathrm{pF}$, respectively; $p<0.001$, unpaired $t$ test). Within the second group, HVA $I_{\mathrm{Ca}}$ was nearly abolished in neurons expressing GFP-Rem2t compared with neurons expressing GFP $(110 \pm 19$ and $4.87 \pm 1.1 \mathrm{pA} / \mathrm{pF}$, respectively; $p=0.003$, unpaired $t$ test). Therefore, we conclude that expression of GFPRem $2 t$ in DRG neurons selectively suppressed current arising from all $\mathrm{HVA} \mathrm{Ca}^{2+}$ channel types, although having little or no effect on endogenous LVA-type $\mathrm{Ca}^{2+}$ channels. In addition to providing insight into the mechanism of Rem 2 action, the results of these experiments show that LVA-type $\mathrm{Ca}^{2+}$ channels of DRG neurons can be effectively isolated without using a mixture of HVA-type $\mathrm{Ca}^{2+}$ channel blockers.

Expression of Rem 2 abolished $I_{\mathrm{Ca}}$ recorded from tsA201 cells stably expressing $\mathrm{N}$-type channels without affecting surface expression

The preceding data have demonstrated that heterologous expression of Rem 2 dramatically reduced the amplitude of $I_{\mathrm{Ca}}$ derived from the endogenous $\mathrm{N}$-type $\mathrm{Ca}^{2+}$ channels in sympathetic neurons and HVA $\mathrm{Ca}^{2+}$ channels in primary sensory neurons. Mechanistically, a key question is whether the $\mathrm{Ca}^{2+}$ channels were removed from or remained at the cell surface after Rem2 expression. To address this issue, we opted to use tsA201 cells stably expressing molecularly defined $\mathrm{N}$-type $\mathrm{Ca}^{2+}$ channels composed of $\mathrm{Ca}_{\mathrm{v}} \alpha_{1} 2.2 / \beta 3 / \alpha_{2} \delta$ (Lin et al., 2004). This cell line expresses functional $\mathrm{Ca}^{2+}$ channels at high density (Lin et al., 2004) and supports a high transfection efficiency (at least $60 \%$ as shown in Fig. 7D). The data in Figure $7 A$ show that $\mathrm{N}$-type $I_{\mathrm{Ca}}$ was abolished in cells transfected with GFP-Rem2t or GFP-Rem2 cDNA for $19-53 \mathrm{~h}(0.16 \pm 0.10$ and $0.71 \pm 0.60 \mathrm{pA} / \mathrm{pF}$, respectively) when compared with cells expressing GFP only $(66.3 \pm$ $13.1 \mathrm{pA} / \mathrm{pF})$, thereby recapitulating the results obtained in the
A.

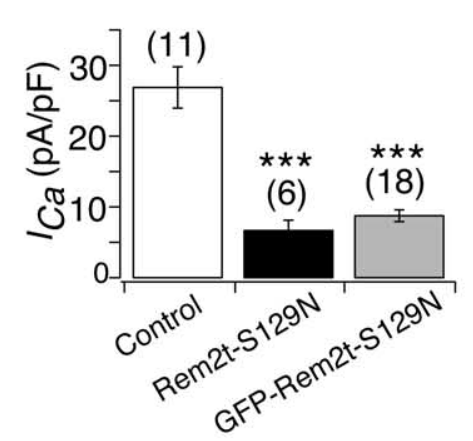

B.

C.
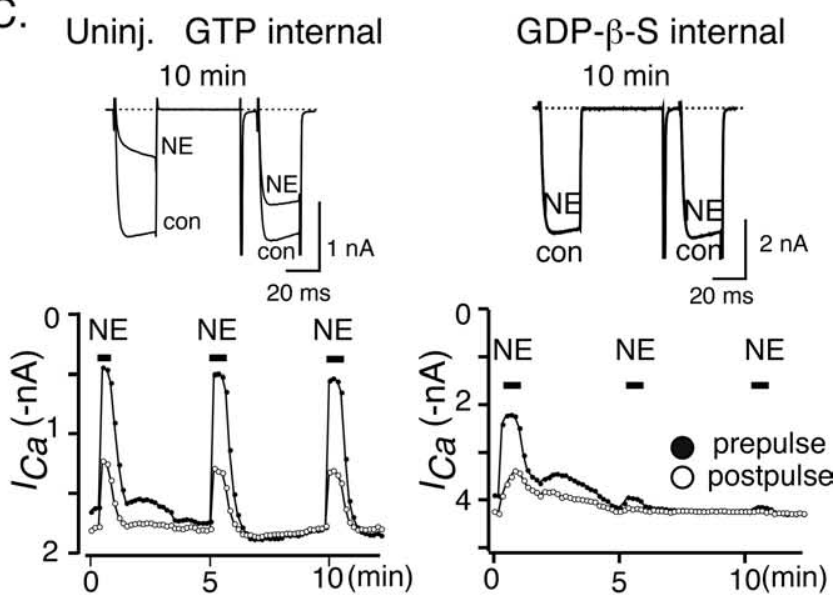

D.

E. GDP- $\beta-S$ internal GDP- $\beta-S$ internal
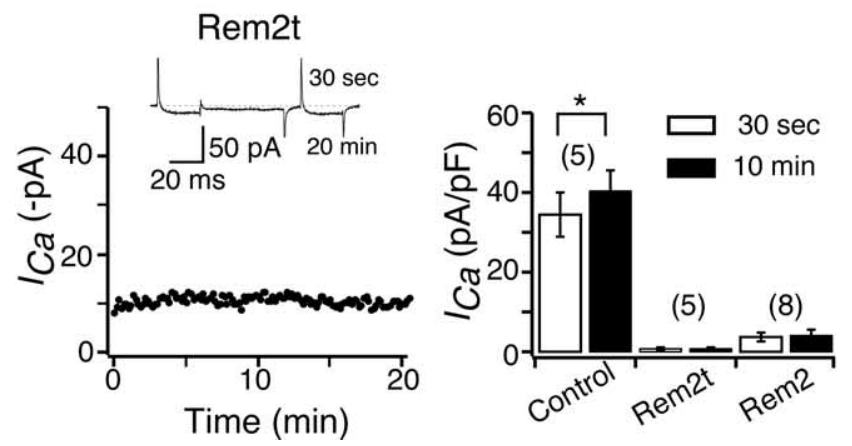

Figure 5. GTP binding may not be required for Rem2-mediated downregulation of $I_{\mathrm{Ca}}$ in sympathetic neurons. A, Average $\pm \mathrm{SEM} / \mathrm{Ca}_{\mathrm{a}}$ density in control neurons (open bar) and neurons expressing (filled bars) Rem2t-S129N or GFP-Rem2t-S129N. $I_{\mathrm{Ca}_{\mathrm{a}}}$ density was calculated as in Figure $1 C .{ }^{* * *} p<0.001$ versus control neurons, ANOVA. $\boldsymbol{B}$, Fluorescent micrographs were taken from COS-7 cells $\sim 24 \mathrm{~h}$ after transfection with GFP-Rem2t or GFP-Rem2t-S129N CDNA constructs as indicated. $C$, Comparison of NE-mediated inhibition of $I_{\mathrm{Ca}}$ recorded with pipette solutions containing either GTP (left) or GDP- $\beta$-S (right). $I_{\mathrm{Ca}}$ was evoked as in Figure $2 A$. D , Time course of $I_{\mathrm{Ca}}$ recorded from a neuron expressing Rem 2 t. GDP- $\beta$-S $(2 \mathrm{~mm})$ was included in the patch-pipette solution. Superimposed $I_{\mathrm{Ca}_{\mathrm{a}}}$ traces recorded at $30 \mathrm{~s}$ and $20 \mathrm{~min}$ after patch rupture. $\boldsymbol{E}$, Mean $\pm \mathrm{SEM} / \mathrm{Ca}_{\mathrm{a}}$ density at 30 s and $10 \mathrm{~min}$ after the establishment of whole-cell recording $(2$ mм GDP- $\beta$-S was included in the pipette solution) in control neurons and neurons expressing Rem2t or Rem2. ${ }^{*} p<0.05$, paired $t$ test. Uninj., Uninjected; con, control.

neuronal systems. To examine whether Rem 2 alters $\mathrm{Ca}^{2+}$ channel density at the cell surface, a live-cell surface ligand-binding assay was performed with cells cultured in 24-well plates. As summarized in Figure $7 B$, application of $\left[{ }^{125} \mathrm{I}\right] \mathrm{Tyr}^{22}-\omega$-conotoxin GVIA $(1 \mathrm{nM}, 300 \mu \mathrm{l})$, an antagonist specific to N-type $\mathrm{Ca}^{2+}$ chan- 
A.

\section{DRG neurons}
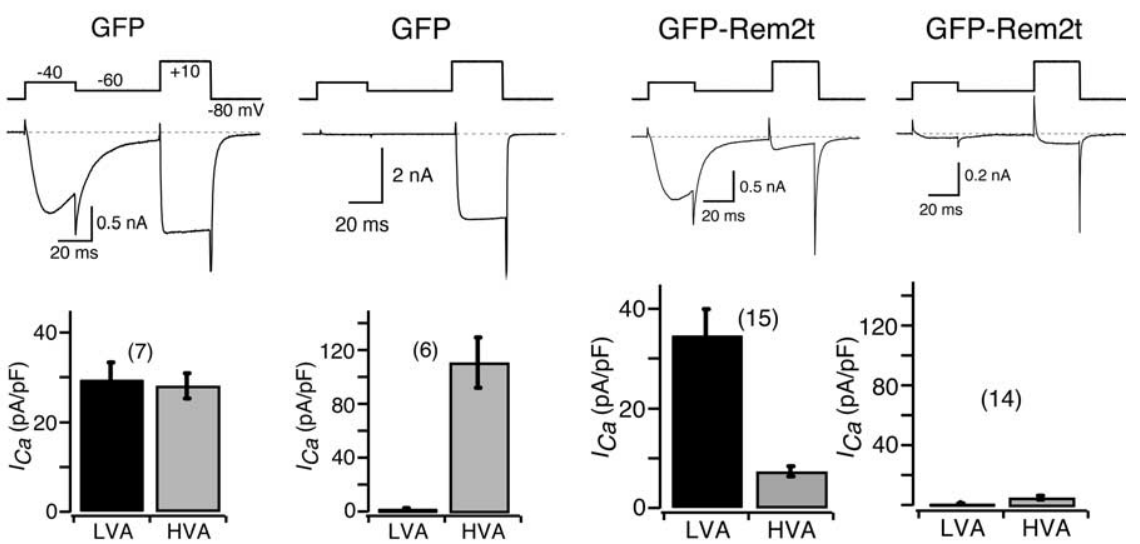

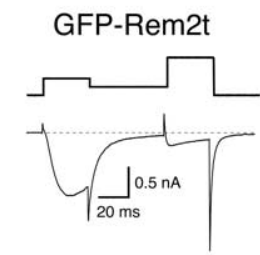

DRG neurons

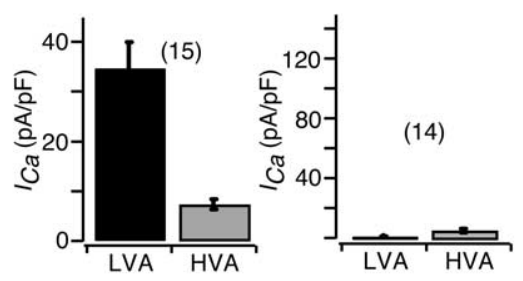

Figure 6. Expression of GFP-Rem2t in DRG neurons attenuated HVA but spared LVAI $I_{\mathrm{Ca}} \cdot A, I_{\mathrm{Ca}}$ traces recorded from two separate DRG neurons infected with Ad-GFP. The left panel illustrates a neuron with a large LVA I camponent. The right panel illustrates a neuron with negligible LVA $I_{\mathrm{Ca}}$. The voltage protocol used to evoke $I_{\mathrm{Ca}}$ is illustrated above the traces. The current evoked at -40 $\mathrm{mV}$ arises from LVA $\mathrm{Ca}^{2+}$ channels, whereas the current evoked at $+10 \mathrm{mV}$ arises primarily from HVA $\mathrm{Ca}^{2+}$ channels (see Materials and Methods). To facilitate analysis, DRG neurons were divided into a group displaying a high density of LVA Ca $_{\text {a }}(>15$ $\mathrm{pA} / \mathrm{pF}$; left) and a group displaying virtually no $\mathrm{LVA} I_{\mathrm{Ca}}\left(<3 \mathrm{pA} / \mathrm{pF}\right.$; right). Bar graphs summarizing the average $I_{\mathrm{Ca}}$ density arising from LVA (black) and HVA (gray) channels 36-48 h after infection with Ad-GFP. $\boldsymbol{B}$, The same analysis as shown in $\boldsymbol{A}$ for neurons infected with adenoviruses expressing GFP-Rem2t. LVA $I_{\mathrm{Ca}}$ amplitude was measured $15 \mathrm{~ms}$ after initiation of the voltage step to

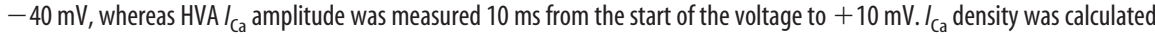
from $I_{\mathrm{Ca}}$ amplitude normalized to cell membrane capacitance. Number of neurons tested is shown in parentheses.

nels (Terlau and Olivera, 2004), to wells containing the overnight culture of the stable cell line expressing $\mathrm{Ca}_{\mathrm{v}} \alpha_{1} 2.2 / \beta 3 / \alpha_{2} \delta$ resulted in ligand binding correlated with the number of cells $(22.7 \pm$ $1.1 \times 10^{3} \mathrm{cpm}$ for $0.5 \times 10^{5}$ cells; $32.5 \pm 1.7 \times 10^{3} \mathrm{cpm}$ for $1 \times$ $10^{5}$ cells; and $48.2 \pm 1.4 \times 10^{3}$ cpm for $2 \times 10^{5}$ cells). Note that the number of the cells in each well was measured $\sim 24 \mathrm{~h}$ before the ligand binding assay. Nonspecific ligand binding was $<5 \%$, as estimated from binding to control HEK293 cells devoid of N-type $\mathrm{Ca}^{2+}$ channels. As shown in Figure $7 C, 26 \mathrm{~h}$ after transfection, cells expressing either GFP-Rem $2 t$ or GFP-Rem 2 bound the same amount of the ligand as cells expressing GFP alone $(43.8 \pm 1.9 \times$ $10^{3} ; 43.3 \pm 2.6 \times 10^{3}$, and $44.2 \pm 1.7 \times 10^{3} \mathrm{cpm}$, respectively; $p=0.96$, ANOVA). Similar results were obtained when the concentration of $\left[{ }^{125} \mathrm{I}\right] \mathrm{Tyr}^{22}-\omega$-conotoxin GVIA was doubled in the binding assay (data not shown). Therefore, we conclude that Rem 2 inhibited the activity of $\mathrm{N}$-type $\mathrm{Ca}^{2+}$ channels located at the plasma membrane without affecting surface expression of the $\mathrm{Ca}_{\mathrm{v}} \alpha_{1} 2.2$ subunit. This conclusion was based on assumptions that the expression of Rem 2 does not alter the radioligand equilibrium dissociation constant $\left(K_{\mathrm{d}}\right)$ and that the nonspecific binding measured from HEK293 cells is reflective of tsA201 cells.

\section{Discussion}

Kir/Gem, Rad, Rem, and Rem 2 comprise a recently defined family of small Ras-related GTP-binding proteins termed RGK proteins. Unique features of this family are the ability to directly interact with $\mathrm{Ca}_{\mathrm{v}} \beta$ and greatly reduce $I_{\mathrm{Ca}}$ arising from $\mathrm{HVACa}^{2+}$ channels in both heterologous and native expression systems (Béguin et al., 2001; Finlin et al., 2003, 2005; Murata et al., 2004; Ward et al., 2004). Among the RGK family, Rem 2 stands out as the sole member displaying a high level of expression in the CNS (Finlin et al., 2000). Given the importance of $\mathrm{HVA} \mathrm{Ca}^{2+}$ channels in regulating neuronal excitability and synaptic function, we ex- amined the effects of expressing Rem 2 on endogenous neuronal $\mathrm{Ca}^{2+}$ channels in mammalian neurons.

\section{Mechanisms of Rem2-mediated decrease in $I_{\mathrm{Ca}}$ density}

Several distinct mechanisms could underlie the decrease in $I_{\mathrm{Ca}}$ density after Rem2 expression. First, Rem 2 might accelerate the degradation and/or internalization of $\mathrm{Ca}^{2+}$ channels, leading to a decrease in the surface density of channels. Our data seem to firmly rule out this possibility because binding of $\left[{ }^{125} \mathrm{I}\right] \mathrm{Tyr}^{22}-\omega$-conotoxin GVIA, a specific high-affinity antagonist of N-type $\mathrm{Ca}^{2+}$ channels (Terlau and Olivera, 2004), was unaltered after Rem 2 expression for $26 \mathrm{~h}$ (Fig. 7). At this time, whole-cell patch-clamp recordings demonstrated a virtual elimination of $I_{\mathrm{Ca}}$. Because $\omega$-conotoxin GVIA binds to $\mathrm{Ca}_{\mathrm{v}} \alpha_{1} 2.2$, the subunit conferring ion permeation and voltage-sensitive gating, we cannot rule out the degradation or removal of $\mathrm{Ca}_{\mathrm{V}} \beta$ (or perhaps other auxiliary subunits), a possibility that will be considered later. Second, an inhibition of $\mathrm{Ca}^{2+}$ channel synthesis (without compensatory alterations in channel removal) would eventually lead to a decrease in $I_{\mathrm{Ca}}$ density. In this regard, expression of truncated $\mathrm{Ca}_{\mathrm{v}} \alpha_{1} 2.2$ inhibits channels synthesis (Raghib et al., 2001) via activation of an endoplasmic reticulum resident RNA-dependent kinase, PERK (PKR-like endoplasmic reticulum eIF2 $\alpha$ kinase) (Page et al., 2004). Similar effects result from the expression of the CACNG7 gene product, $\mathrm{Ca}_{\mathrm{V}} \gamma_{7}$, although the mechanism remains to be determined (Moss et al., 2002). The inability of a global protein translation inhibitor cycloheximide to reduce $I_{\mathrm{Ca}}$ density in sympathetic neurons at a time when Rem 2 expression produced significant $I_{\mathrm{Ca}}$ reduction argues against this mechanism for mediating the short-term effects of Rem2 expression (Figs. 1, 2). In agreement with our cycloheximide data, expression of $\mathrm{Ca}_{\mathrm{V}} \gamma_{7}$ for $36-48 \mathrm{~h}$ did not affect $I_{\mathrm{Ca}}$ in sympathetic neurons (Moss et al., 2002), thus implicating a relatively long channel half-life. For this reason, we cannot exclude potential effects of Rem 2 on $\mathrm{Ca}^{2+}$ channel synthesis but can eliminate this mechanism as an explanation for the decrease in $I_{\mathrm{Ca}}$ density seen after $\sim 24 \mathrm{~h}$ of Rem 2 expression. Third, Rem 2 might interfere with assembly and trafficking of $\mathrm{Ca}_{\mathrm{V}}$ subunits to the plasma membrane surface. In the seminal work of Béguin et al. (2001), expression of Kir/Gem was shown to eliminate functional L-type $\mathrm{Ca}^{2+}$ channels in HEK293 cells after concurrent transfection with both $\mathrm{Kir} / \mathrm{Gem}$ and $\mathrm{Ca}_{\mathrm{V}}$ subunits. Immunostaining of the epitope-tagged $\mathrm{Ca}_{\mathrm{V}} \alpha_{1} 1.2$ demonstrated a disruption of trafficking to the cell surface, suggesting a connection with studies showing that $\mathrm{Ca}_{\mathrm{V}} \beta$ s are required for appropriate $\mathrm{Ca}_{\mathrm{V}} \alpha_{1}$ trafficking (Bichet et al., 2000a). Consistent with this notion, prolonged expression of Kir/Gem in guinea pig cardiomyocytes reduced the number of the functional L-type $\mathrm{Ca}^{2+}$ channels, as evidenced by a marked reduction in gating current (Murata et al., 2004). Finally, recent studies performed with Rem 2 also demonstrated a block of $\mathrm{Ca}_{\mathrm{V}} \alpha_{1} 1.2$ surface expression (Béguin et al., 2005). Thus, it was surprising to find that surface expression of $\mathrm{Ca}_{\mathrm{V}} \alpha_{1} 2.2$ in a stably expressing cell line was unaltered by Rem2 
expression (Fig. 7). In support of this finding, Finlin et al. (2005) reported that L-type channel surface expression in the MIN6 mouse insulinoma line was not reduced (as determined from surface biotinylation) at a time when channel activity was potently inhibited. Therefore, although Rem 2 can alter the trafficking of L-type $\mathrm{Ca}^{2+}$ channels in some cell types, this appears not to be the mechanism by which it inhibits $\mathrm{Ca}^{2+}$ channels in the SCG, DRG neurons, and tsA201 cells in our study. Thus, Rem 2 may alter $\mathrm{Ca}^{2+}$ channel function via two distinct pathways. One pathway disrupts $\mathrm{Ca}_{\mathrm{V}}$ subunit trafficking and would require turnover of endogenous channels before functional effects were evident, a mechanism well suited for setting the steady-state level of channels. The other pathway, discussed below, involves modulation of preexisting channels and is thus more suitable for dynamically regulating $\mathrm{Ca}^{2+}$ channel activity on a more rapid timescale.

\section{Modulation of preexisting $\mathrm{Ca}^{2+}$ channels by Rem2}

Given the extensive evidence for the direct interaction of RGK proteins with $\mathrm{Ca}_{\mathrm{V}} \beta$, an attractive hypothesis is that binding of Rem 2 disrupts the $\mathrm{Ca}_{\mathrm{V}} \beta$ interaction with $\mathrm{Ca}_{\mathrm{V}} \alpha$, thereby creating a population of channels at the cell surface devoid of $\mathrm{Ca}_{\mathrm{V}} \beta$. In support of this notion, there is limited evidence showing that $\mathrm{Kir} / \mathrm{Gem}$ interferes with the $\mathrm{Ca}_{\mathrm{V}} \alpha / \beta$ interaction (Béguin et al., 2001, their supplement; Sasaki et al., 2005) and that this interaction may be reversible (Bichet et al., 2000b). The latter finding is controversial because the in vitro determined affinity of $\mathrm{Ca}_{\mathrm{V}} \beta$ for the $\mathrm{Ca}_{\mathrm{V}} \alpha$ I-II linker domain is extremely high (for review, see Richards et al., 2004). Although this mechanism could explain defects in the trafficking of newly synthesized (i.e., before subunit assembly) $\mathrm{Ca}^{2+}$ channels, our data do not support such a mechanism for preexisting channels. First, Rem 2 expression abolished (below detectable levels) $I_{\mathrm{Ca}}$ in a subset of both SCG neurons and in cells stably expressing $\mathrm{N}$-type $\mathrm{Ca}^{2+}$ channels. This result is contrary to data obtained from $\mathrm{HVA} \mathrm{Ca}{ }^{2+}$ channels expressed without overt $\mathrm{Ca}_{\mathrm{V}} \beta$ in which detectable current flowing through the modified channels was recorded (Meir et al., 2000; Yasuda et al., 2004). Second, the loss of $\mathrm{Ca}_{\mathrm{V}} \beta$ would be expected to shift the activation of the channel to more depolarized potentials (Dolphin, 2003). In Rem2-expressing SCG neurons with an attenuated but detectable $I_{\mathrm{Ca}}$, the voltage dependence of activation and kinetics of $I_{\mathrm{Ca}}$ appeared unaltered (Fig. $1 A, D$ ). In addition, the magnitude and characteristics (i.e., voltage dependent) of $I_{\mathrm{Ca}}$ block produced by NE was similar for the residual $I_{\mathrm{Ca}}$ and unmodified channels (Fig. $1 E, F$ ). The loss of $\mathrm{Ca}_{\mathrm{V}} \beta$ would be expected to render the inhibition much weaker and voltage independent (Meir et al., 2000).

A remaining hypothesis, which we currently favor, is that Rem 2 interacts with the $\mathrm{Ca}_{\mathrm{V}} \beta$ of assembled $\mathrm{HVA} \mathrm{Ca}^{2+}$ channels at the plasma membrane to form a nonconducting species. At this point, the evidence, as outlined above, is circumstantial, and additional experiments are necessary to either exclude or validate the hypothesis. The finding that preexisting $\mathrm{LVA} \mathrm{Ca}^{2+}$ channels of DRG neurons were spared by Rem 2 expression (Fig. 6) supports a mechanism that requires $\mathrm{Ca}_{\mathrm{V}} \beta$ as heterologous expression of the $\mathrm{Ca}_{\mathrm{V}} \alpha_{1}$ 3.x subunit alone recapitulates native T-type channel properties (Perez-Reyes, 2002). Recent studies of $\mathrm{Ca}_{\mathrm{V}} \beta$ structure have confirmed previous predictions (Hanlon et al., 1999) of similarity between $\mathrm{Ca}_{\mathrm{V}} \beta$ and the MAGUK (membraneassociated guanylate kinase) class of proteins and further revealed that the interaction between $\mathrm{Ca}_{\mathrm{V}} \beta$ and $\mathrm{Ca}_{\mathrm{V}} \alpha$ I-II loop occupies only a small area (Chen et al., 2004b; Opatowsky et al., 2004; Van Petegem et al., 2004). Thus, the majority of the $\mathrm{Ca}_{\mathrm{V}} \beta$ surface in the preassembled channels is potentially available to interact with
A.

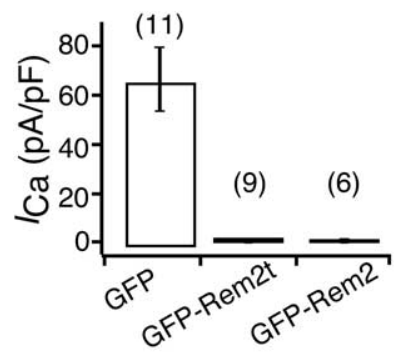

C.
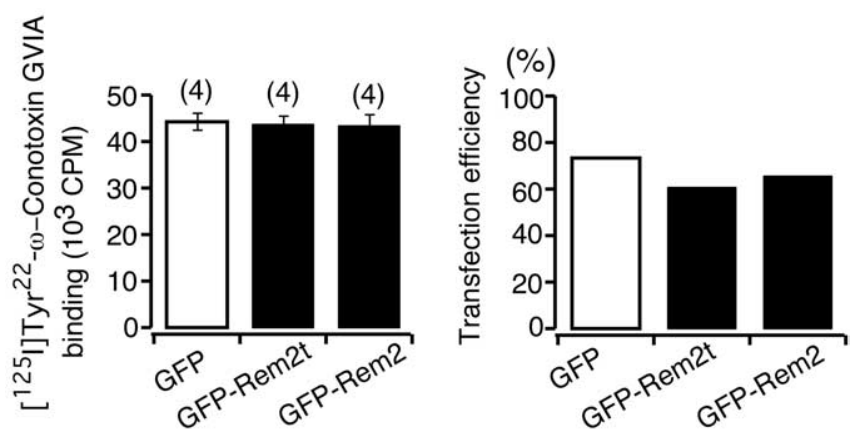

Figure 7. Heterologous expression of Rem 2 in tsA201 cells stably expressing $C_{v} \alpha_{1} 2.2 / \beta 3 /$ $\alpha_{2} \delta$ abolished $I_{\mathrm{Ca}}$ without affecting $\omega$-conotoxin GVIA binding. $A$, Bar graphs summarizing the average $I_{C a}$ density of cells transfected $19-53 \mathrm{~h}$ earlier with CDNA constructs encoding GFP, GFP-Rem2t, or GFP-Rem2. I Ca $_{\text {a }}$ density was calculated as in Figure 1C. The number of cells tested is shown in parentheses. $\boldsymbol{B}$, Comparison of $\left[{ }^{125} \mid\right] \mathrm{Tyr}^{22}-\omega$-conotoxin GVIA binding to different numbers of tsA201 cells expressing $\mathrm{Ca}^{2+}$ channels. To compensate for potential nonspecific binding, HEK293 cells were added to maintain a total of $2 \times 10^{5}$ cells per well. After overnight culture, cells were incubated with [ ${ }^{125}$ I]Tyr ${ }^{22}-\omega$-conotoxin GVIA (1 nM) for 40 min and washed thoroughly, and the bound ligand was quantified with a scintillation counter. $\boldsymbol{C}$, Mean $\left[{ }^{125} \mathrm{I}\right] \mathrm{Tyr}^{22}-\omega$-conotoxin GVIA bound to tsA201 cells $26 \mathrm{~h}$ after transfection with CDNA constructs encoding GFP, GFP-Rem2t, or GFP-Rem2. D, Transfection efficiency (measured as the percentage of cells displaying GFP fluorescence) was determined from parallel experiments. A total of 500 cells were examined for each construct by phase contrast and epifluorescence microscopy ( $40 \times$ objective, 0.60 numerical aperture).

other proteins. One can speculate that Rem2 (and other RGK proteins) interacts with a region of $\mathrm{Ca}_{\mathrm{V}} \beta$, thereby altering the interaction of $\mathrm{Ca}_{\mathrm{V}} \alpha / \beta$ and/or the interaction between Src homology 3 and guanylate kinase domains within the conserved $\mathrm{Ca}_{\mathrm{V}} \beta$ core region.

\section{Regulation of Rem2 function}

Regardless of the mechanisms by which Rem2 suppresses preexisting $\mathrm{Ca}^{2+}$ channel function, it was of interest to explore elements of Rem 2 that conferred this phenomenon. As a class, Rasrelated proteins are molecular switches controlled by the binding of GTP. As with heterotrimeric G-proteins, the canonical pathway involves the exchange of GDP for GTP, often facilitated by a GEF-type molecule, which promotes transition of the protein from the inactive to active state (Takai et al., 2001). Kir/Gem conforms to this paradigm because a point mutation that disrupts GTP binding rendered the protein impotent in regard to HVA Ca ${ }^{2+}$ channel suppression (Ward et al., 2004; Sasaki et al., 2005). The cognate mutation (S66N) in Rad also resulted in total loss of GTP binding (Zhu et al., 1995), although the functional consequence has not been tested. Unexpectedly, the cognate mu- 
tation $(\mathrm{S} 129 \mathrm{~N})$ in Rem2 was without effect (Fig. 5A), thus undermining the role of GTP binding in the $\mathrm{Ca}^{2+}$ channel-suppressing actions of Rem2. At present, there is no direct evidence that this mutation disrupts GTP binding to Rem2. However, the extensive homology of the G1 region (containing the S129 residue) and data from cognate mutations of related proteins Gem and Rad (Zhu et al., 1995; Feig, 1999; Ward et al., 2004) corroborates the interpretation. In addition, Béguin et al. (2005) report that the S129N mutation impairs the ability of Rem2 to interact with $\mathrm{Ca}_{\mathrm{V}} \beta$, thus providing additional evidence for the function of this residue. Although the latter result appears at odds with the findings reported here, it is possible that the S129N mutation decreases, but does not eliminate, the affinity of Rem 2 for $\mathrm{Ca}_{\mathrm{V}} \beta$. In addition, dialysis of the neuron with GDP- $\beta$-S via the patch pipette did not reverse Rem2-mediated channel inhibition (Fig. $5 D$ ), although $\mathrm{Ca}^{2+}$ channel modulation by heterotrimeric G-proteins was abolished (Fig. 5C). Our data indicate that Rem2, in terms of $\mathrm{Ca}^{2+}$ channel suppression, may bypass the canonical G-protein pathway and that different RGK proteins may use distinct activation mechanisms to produce similar functional effects. Future experiments designed to directly measure the affinity of Rem2 S129N to GTP should help clarify this issue.

The domains flanking the Ras homology core domain of Rem 2 contain protein interaction motifs that may affect function. The $\mathrm{N}$ terminus has a motif for 14-3-3 protein binding, whereas the $\mathrm{C}$ terminus contains a polybasic motif, a well conserved calmodulin-binding motif, and a second 14-3-3 binding motif. Béguin et al. (2005) have demonstrated recently that both 14-3-3 binding domains are required to demonstrate in vitro binding of 14-3-3, presumably in a dimerized form. Because expression of Rem $2 \mathrm{t}$, which lacks the $\mathrm{N}$ terminus 14-3-3 binding site, was as effective as Rem2 (Fig. 1), our data suggest that interaction with 14-3-3 proteins is not required for suppressing $\mathrm{Ca}^{2+}$ channel activity. This result agrees with data obtained from a Rem 2 construct containing point mutations (S69A and S334A) that ablated 14-3-3 binding (Béguin et al., 2005). Deletion of the $\mathrm{C}$ terminus of Rem 2 disrupted $\mathrm{Ca}^{2+}$ channel suppression and targeting of Rem 2 to the plasma membrane (Fig. 4) (Finlin et al., 2000). The latter effect presumably arises from polybasic residues in the $\mathrm{C}$ terminus. Consistent with this proposal, both plasma membrane targeting and $\mathrm{Ca}^{2+}$ channel inhibition could be restored by fusing the last 23 residues of $\mathrm{K}-\mathrm{Ras} 4 \mathrm{~B}$ to the $\mathrm{C}$ terminus of Rem 2 core domain (Fig. 4), which contains both a polybasic motif and a farnesylation site (Prior and Hancock, 2001). Interestingly, fusing the initial 10 residues of $\mathrm{G} \alpha_{\mathrm{i} 1}$, which has a myristoylation/palmitoylation motif (Fivaz and Meyer, 2003), to the N terminus of the Rem 2 core domain did not reconstitute function, although plasma membrane targeting was restored (Fig. 4). Thus, targeting of the Rem 2 core domain to the plasma membrane was necessary but not sufficient for attenuating $\mathrm{Ca}^{2+}$ channel function.

\section{References}

Béguin P, Nagashima K, Gonoi T, Shibasaki T, Takahashi K, Kashima Y, Ozaki N, Geering K, Iwanaga T, Seino S (2001) Regulation of $\mathrm{Ca}^{2+}$ channel expression at the cell surface by the small G-protein kir/Gem. Nature 411:701-706.

Béguin P, Mahalakshmi RN, Nagashima K, Cher DH, Kuwamura N, Yamada Y, Seino Y, Hunziker W (2005) Roles of 14-3-3 and calmodulin binding in subcellular localization and function of the small G protein Rem2. Biochem J 390:67-75.

Berrow NS, Brice NL, Tedder I, Page KM, Dolphin AC (1997) Properties of cloned rat $\alpha 1 \mathrm{~A}$ calcium channels transiently expressed in the COS-7 cell line. Eur J Neurosci 9:739-748.
Bichet D, Cornet V, Geib S, Carlier E, Volsen S, Hoshi T, Mori Y, De Waard M (2000a) The I-II loop of the $\mathrm{Ca}^{2+}$ channel $\alpha_{1}$ subunit contains an endoplasmic reticulum retention signal antagonized by the $\beta$ subunit. Neuron 25:177-190.

Bichet D, Lecomte C, Sabatier JM, Felix R, De Waard M (2000b) Reversibility of the $\mathrm{Ca}^{2+}$ channel $\alpha_{1}-\beta$ subunit interaction. Biochem Biophys Res Commun 277:729-735.

Bourne HR, Sanders DA, McCormick F (1991) The GTPase superfamily: conserved structure and molecular mechanism. Nature 349:117-127.

Chen H, Ikeda SR (2004) Modulation of ion channels and synaptic transmission by a human sensory neuron-specific G-protein-coupled receptor, SNSR $4 / \mathrm{mrgX1}$, heterologously expressed in cultured rat neurons. J Neurosci 24:5044-5053.

Chen H, Lambert NA (2000) Endogenous regulators of G protein signaling proteins regulate presynaptic inhibition at rat hippocampal synapses. Proc Natl Acad Sci USA 97:12810-12815.

Chen H, Honse Y, Ikeda SR (2004a) Alternative modalities of adenovirusmediated gene expression in hippocampal neurons cultured on microisland substrate. Neurosci Lett 368:221-225.

Chen YH, Li MH, Zhang Y, He LL, Yamada Y, Fitzmaurice A, Shen Y, Zhang $\mathrm{H}$, Tong L, Yang J (2004b) Structural basis of the $\alpha_{1}-\beta$ subunit interaction of voltage-gated $\mathrm{Ca}^{2+}$ channels. Nature 429:675-680.

Cohen L, Mohr R, Chen YY, Huang M, Kato R, Dorin D, Tamanoi F, Goga A, Afar D, Rosenberg N, Witte O (1994) Transcriptional activation of a ras-like gene (kir) by oncogenic tyrosine kinases. Proc Natl Acad Sci USA 91:12448-12452.

Dolphin AC (2003) $\beta$ subunits of voltage-gated calcium channels. J Bioenerg Biomembr 35:599-620.

Elmslie KS, Zhou W, Jones SW (1990) LHRH and GTP- $\gamma$-S modify calcium current activation in bullfrog sympathetic neurons. Neuron 5:75-80.

Fedulova SA, Kostyuk PG, Veselovsky NS (1985) Two types of calcium channels in the somatic membrane of new-born rat dorsal root ganglion neurones. J Physiol (Lond) 359:431-446.

Feig LA (1999) Tools of the trade: use of dominant-inhibitory mutants of Ras-family GTPases. Nat Cell Biol 1:E25-E27.

Finlin BS, Andres DA (1997) Rem is a new member of the Rad- and Gem/ Kir Ras-related GTP-binding protein family repressed by lipopolysaccharide stimulation. J Biol Chem 272:21982-21988.

Finlin BS, Shao H, Kadono-Okuda K, Guo N, Andres DA (2000) Rem2, a new member of the Rem/Rad/Gem/Kir family of Ras-related GTPases. Biochem J 347:223-231.

Finlin BS, Crump SM, Satin J, Andres DA (2003) Regulation of voltagegated calcium channel activity by the Rem and Rad GTPases. Proc Natl Acad Sci USA 100:14469-14474.

Finlin BS, Mosley AL, Crump SM, Correll RN, Ozcan S, Satin J, Andres DA (2005) Regulation of L-type $\mathrm{Ca}^{2+}$ channel activity and insulin secretion by the Rem2 GTPase. J Biol Chem, in press.

Fivaz M, Meyer T (2003) Specific localization and timing in neuronal signal transduction mediated by protein-lipid interactions. Neuron 40:319-330.

Hamill OP, Marty A, Neher E, Sakmann B, Sigworth FJ (1981) Improved patch-clamp techniques for high-resolution current recording from cells and cell-free membrane patches. Pflügers Arch 391:85-100.

Hanlon MR, Berrow NS, Dolphin AC, Wallace BA (1999) Modelling of a voltage-dependent $\mathrm{Ca}^{2+}$ channel $\beta$ subunit as a basis for understanding its functional properties. FEBS Lett 445:366-370.

He TC, Zhou S, da Costa LT, Yu J, Kinzler KW, Vogelstein B (1998) A simplified system for generating recombinant adenoviruses. Proc Natl Acad Sci USA 95:2509-2514.

Ikeda SR (1991) Double-pulse calcium channel current facilitation in adult rat sympathetic neurones. J Physiol (Lond) 439:181-214.

Ikeda SR (2004) Expression of G-protein signaling components in adult mammalian neurons by microinjection. Methods Mol Biol 259:167-182.

Ikeda SR, Dunlap K (1999) Voltage-dependent modulation of N-type calcium channels: role of G protein subunits. Adv Second Messenger Phosphoprotein Res 33:131-151.

Kostyuk PG, Shuba YM, Savchenko AN (1988) Three types of calcium channels in the membrane of mouse sensory neurons. Pflügers Arch 411:661-669.

Kozak M (1999) Initiation of translation in prokaryotes and eukaryotes. Gene 234:187-208. 
Lee SK, Hollenbeck PJ (2003) Organization and translation of mRNA in sympathetic axons. J Cell Sci 116:4467-4478.

Lin Y, McDonough SI, Lipscombe D (2004) Alternative splicing in the voltage-sensing region of $\mathrm{N}$-type $\mathrm{Ca}_{\mathrm{v}} 2.2$ channels modulates channel kinetics. J Neurophysiol 92:2820-2830.

Maguire J, Santoro T, Jensen P, Siebenlist U, Yewdell J, Kelly K (1994) Gem: an induced, immediate early protein belonging to the Ras family. Science 265:241-244.

Meir A, Bell DC, Stephens GJ, Page KM, Dolphin AC (2000) Calcium channel $\beta$ subunit promotes voltage-dependent modulation of $\alpha 1 \mathrm{~B}$ by $\mathrm{G}_{\beta \gamma}$. Biophys J 79:731-746.

Mintz IM, Adams ME, Bean BP (1992) P-type calcium channels in rat central and peripheral neurons. Neuron 9:85-95.

Moss FJ, Viard P, Davies A, Bertaso F, Page KM, Graham A, Canti C, Plumpton M, Plumpton C, Clare JJ, Dolphin AC (2002) The novel product of a five-exon stargazin-related gene abolishes $\mathrm{Ca}_{\mathrm{v}} 2.2$ calcium channel expression. EMBO J 21:1514-1523.

Murata M, Cingolani E, McDonald AD, Donahue JK, Marban E (2004) Creation of a genetic calcium channel blocker by targeted gem gene transfer in the heart. Circ Res 95:398-405.

Opatowsky Y, Chen CC, Campbell KP, Hirsch JA (2004) Structural analysis of the voltage-dependent calcium channel $\beta$ subunit functional core and its complex with the $\alpha_{1}$ interaction domain. Neuron 42:387-399.

Page KM, Heblich F, Davies A, Butcher AJ, Leroy J, Bertaso F, Pratt WS, Dolphin AC (2004) Dominant-negative calcium channel suppression by truncated constructs involves a kinase implicated in the unfolded protein response. J Neurosci 24:5400-5409.

Perez-Reyes E (2002) Molecular physiology of low-voltage-activated T-type calcium channels. Physiol Rev 83:117-161.

Prior IA, Hancock JF (2001) Compartmentalization of Ras proteins. J Cell Sci 114:1603-1608.

Raghib A, Bertaso F, Davies A, Page KM, Meir A, Bogdanov Y, Dolphin AC (2001) Dominant-negative synthesis suppression of voltage-gated calcium channel $\mathrm{Ca}_{\mathrm{V}} 2.2$ induced by truncated constructs. J Neurosci 21:8495-8504.

Regan LJ, Sah DWY, Bean BP (1991) $\mathrm{Ca}^{2+}$ channels in rat central and pe- ripheral neurons: high-threshold current resistant to dihydropyridine blockers and $\omega$-conotoxin. Neuron 6:269-280.

Reynet C, Kahn CR (1993) Rad: a member of the Ras family overexpressed in muscle of type II diabetic humans. Science 262:1441-1444.

Richards MW, Butcher AJ, Dolphin AC (2004) $\mathrm{Ca}^{2+}$ channel $\beta$-subunits: structural insights AID our understanding. Trends Pharmacol Sci $25: 626-632$.

Sasaki T, Shibasaki T, Beguin P, Nagashima K, Miyazaki M, Seino S (2005) Direct inhibition of the interaction between alpha-interaction domain and $\beta$-interaction domain of voltage-dependent $\mathrm{Ca}^{2+}$ channels by Gem. J Biol Chem 280:9308-9312.

Schofield GG (1991) Norepinephrine inhibits a $\mathrm{Ca}^{2+}$ current in rat sympathetic neurons via a G-protein. Eur J Pharmacol 207:195-207.

Takai Y, Sasaki T, Matozaki T (2001) Small GTP-binding proteins. Physiol Rev 81:153-208.

Terlau H, Olivera BM (2004) Conus venoms: a rich source of novel ion channel-targeted peptides. Physiol Rev 84:41-68.

Van Petegem F, Clark KA, Chatelain FC, Minor DL Jr (2004) Structure of a complex between a voltage-gated calcium channel $\beta$-subunit and an $\alpha$-subunit domain. Nature 429:671-675.

Ward Y, Spinelli B, Quon MJ, Chen H, Ikeda SR, Kelly K (2004) Phosphorylation of critical serine residues in Gem separates cytoskeletal reorganization from down-regulation of calcium channel activity. Mol Cell Biol 24:651-661.

Yasuda T, Chen L, Barr W, McRory JE, Lewis RJ, Adams DJ, Zamponi GW (2004) Auxiliary subunit regulation of high-voltage activated calcium channels expressed in mammalian cells. Eur J Neurosci 20:1-13.

Yusaf SP, Goodman J, Pinnock RD, Dixon AK, Lee K (2001) Expression of voltage-gated calcium channel subunits in rat dorsal root ganglion neurons. Neurosci Lett 311:137-141.

Zhu J, Reynet C, Caldwell JS, Kahn CR (1995) Characterization of Rad, a new member of Ras/GTPase superfamily, and its regulation by a unique GTPase-activating protein (GAP)-like activity. J Biol Chem 270:48054812. 